
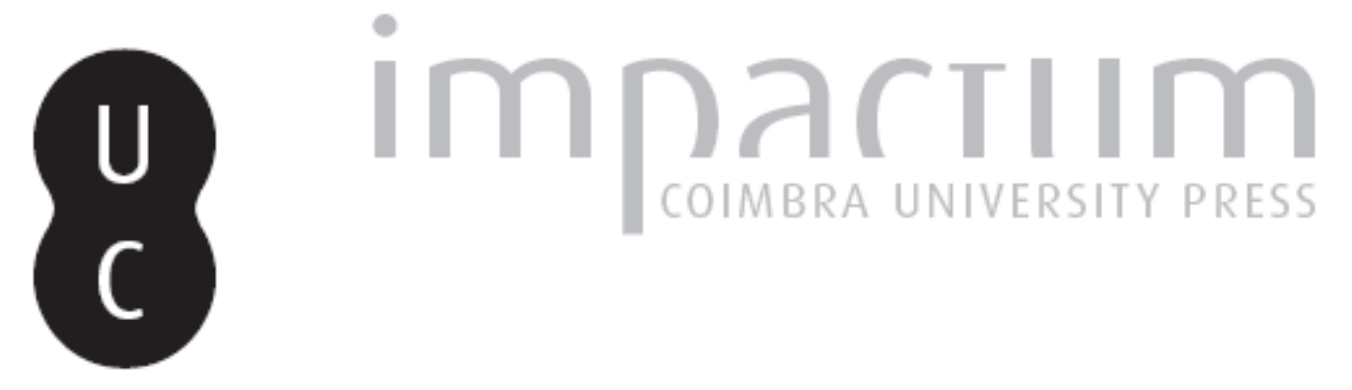

\title{
Heidegger e a solidão da filosofia
}

\section{Autor(es): Lima, Paulo Alexandre}

Publicado por: Faculdade de Letras da Universidade de Coimbra, Instituto de Estudos

URL $\quad$ URI:http://hdl.handle.net/10316.2/34107

DOI: $\quad$ DOI:http://dx.doi.org/10.14195/0872-0851_44_9

Accessed : $\quad$ 26-Apr-2023 16:37:17

A navegação consulta e descarregamento dos títulos inseridos nas Bibliotecas Digitais UC Digitalis, UC Pombalina e UC Impactum, pressupõem a aceitação plena e sem reservas dos Termos e Condições de Uso destas Bibliotecas Digitais, disponíveis em https://digitalis.uc.pt/pt-pt/termos.

Conforme exposto nos referidos Termos e Condições de Uso, o descarregamento de títulos de acesso restrito requer uma licença válida de autorização devendo o utilizador aceder ao(s) documento(s) a partir de um endereço de IP da instituição detentora da supramencionada licença.

Ao utilizador é apenas permitido o descarregamento para uso pessoal, pelo que o emprego do(s) título(s) descarregado(s) para outro fim, designadamente comercial, carece de autorização do respetivo autor ou editor da obra.

Na medida em que todas as obras da UC Digitalis se encontram protegidas pelo Código do Direito de Autor e Direitos Conexos e demais legislação aplicável, toda a cópia, parcial ou total, deste documento, nos casos em que é legalmente admitida, deverá conter ou fazer-se acompanhar por este aviso.

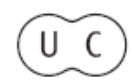






vol. 22 - número 44 - outubro 2013

vol. 22 - número 44 - outubro 2013 Fundação Eng. António de Almeida

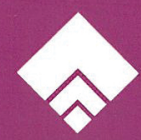




\title{
HEIDEGGER E A SOLIDÃO DA FILOSOFIA
}

\author{
PAULO ALEXANDRE LIMA*
}

\author{
À minha avó \\ que nunca me faltou \\ "Tudo é sabido onde \\ alguma coisa fala de si própria \\ e de falar de isso \\ e de falar de falar. \\ Aquilo que está cada vez mais longe, \\ a pura falta de coisa nenhuma, \\ é o que Conhece e É \\ a sua indizível inexistência. \\ Nós, os maus, onde \\ é fora de fora de tudo, \\ eternamente regressamos \\ ao sítio de onde nunca saímos." \\ Manuel António Pina ${ }^{1}$
}

Resumo: O mais das vezes, tende-se a considerar o fenómeno da solidão apenas como um dos temas possíveis da filosofia. No presente estudo, ao invés, pretende-se apresentar a solidão como o fenómeno fundamental da filosofia: aquele de que a filosofia nasce e com que mais propriamente se ocupa, ao ocupar-se consigo mesma. Ao escolhermos Heidegger como guia, duas das estações incontornáveis do itinerário a seguir são a análise do fenómeno da saudade e a análise do fenómeno do tédio profundo. A tese de Heidegger é a de que a solidão, enquanto condição da filosofia e da existência humana em geral, se exprime por via daquilo a que costumamos cha-

* Unidade I\&D Linguagem, Interpretação \& Filosofia (Faculdade de Letras, Universidade de Coimbra).

1 “A pura falta”, apud MANUEL ANTÓNIO PINA, Todas as palavras - Poesia reunida (1974-2011), Lisboa, Assírio \& Alvim, 2012, p. 86. 
mar saudade e que Heidegger procura conceber a partir do que designa como tédio profundo. Neste sentido, o nosso propósito fundamental é o de perceber como é que Heidegger entende: 1) a relação entre a saudade e o tédio profundo, 2) a relação entre estes dois fenómenos e o da solidão e 3) a relação entre a solidão, a filosofia e a existência humana.

Palavras-chave: Heidegger, solidão, filosofia, saudade, tédio, existência

\begin{abstract}
Most of the time one tends to consider the phenomenon of solitude as simply one of the possible themes in philosophical research. In this study, however, we intend to present solitude as a most fundamental theme in philosophical research - one with which philosophical research occupies itself in order to grasp the very meaning of its own activity. Because we chose Heidegger as guide, two of the fundamental stages of our itinerary are the analysis of nostalgia and that of profound boredom. Heidegger's thesis is that solitude (conceived as the very nature of philosophy and of human existence in general) expresses itself through nostalgiaa phenomenon that Heidegger connects with profound boredom. The fundamental purpose of our study, therefore, is to explain how Heidegger understands: 1) the relationship between nostalgia and profound boredom, 2) the relationship between these phenomena and the phenomenon of solitude and 3) the relationship between solitude, philosophy and human existence.
\end{abstract}

Keywords: Heidegger, solitude, philosophy, nostalgia, boredom, existence

\title{
A filosofia como saudade (Heimweh)
}

É o próprio Heidegger quem - em GA 29/30 (Die Grundbegriffe der Metaphysik: Welt - Endlichkeit - Einsamkeit $)^{2}$ — define, a partir de um fragmento de Novalis, a filosofia como uma "saudade" ou uma "pulsão" para em toda a parte estar em casa:

"Novalis sagt einmal in einem Fragment: »Die Philosophie ist eigentlich Heimweh, ein Trieb überall zu Hause zu sein«."3

Mas que é que pode querer dizer esta "saudade" (Heimweh), esta "pulsão" (Trieb)? E, além disso, que é que significa "em toda a parte estar em casa" (überall zu Hause sein)? Enfim, que "em casa" (zu Hause) é este?

2 M. HEIDEGGER, Gesamtausgabe. II. Abteilung: Vorlesungen 1919-1944. Band 29/30: Die Grundbegriffe der Metaphysik. Welt - Endlichkeit - Einsamkeit. Freiburger Vorlesung Wintersemester 1929/30. Herausgegeben von Friedrich-Wilhelm von Herrmann. Frankfurt am Main, Vittorio Klostermann, 1983, 3. Auflage 2004 [=GA 29/30].

3 GA 29/30 7. 
Ora, Heidegger - após formular tais questões - procura responder-lhes e, com isso, dá-nos indicações decisivas para podermos perceber que é que se acha em causa na filosofia (na "saudade" ou na "pulsão" que parece constituir a filosofia enquanto tal):

"Was ist damit — Philosophie ein Heimweh? Novalis erläutert selbst: »ein Trieb überall zu Hause zu sein«. Ein solcher Trieb kann Philosophie nur sein, wenn wir, die philosophieren, überall nicht zu Hause sind. Wonach steht das Verlangen dieses Triebes? Überall zu Hause zu sein — was heißt das? Nicht nur da und dort, auch nicht nur jeden Orts, an allen nacheinander zusammen, sondern überall zu Hause sein heißt: jederzeit und zumal im Ganzen sein. Dieses >im Ganzen < und seine Gänze nennen wir die Welt. Wir sind, und sofern wir sind, warten wir immer auf etwas. Wir sind immer von Etwas als Ganzem angerufen. Dieses >im Ganzen ist die Welt."

\section{Saudade e inospitalidade (Unheimlichkeit)}

Assim, Heidegger diz-nos que - no centro do próprio acontecimento da filosofia - está uma "saudade" ou "nostalgia" (Heimweh), um "impulso" ou uma "pulsão" (Trieb); mas diz-nos também que — na base do acontecimento em questão - se acha uma "exigência" ou "petição" (Verlangen): um ser "chamado" ou "interpelado" (angerufen) por "algo" (Etwas).

Trata-se pois de um acontecimento em que aquilo de que se sente "saudade" ou "nostalgia" - para que se tem "impulso" ou "pulsão" — é algo cuja presença se "exige" ou "reclama". E esse algo - esse algo que nos "chama" ou "interpela" - é para Heidegger o "mundo" (Welt): o mundo "no seu todo" ou na sua "totalidade" (im Ganzen).

Dito de outro modo: o mundo na sua totalidade é aquilo de que (no acontecimento da filosofia) se sente "saudade" ou "nostalgia"; aquilo para que (na filosofia) se "tende" ou é "impelido"; aquilo que nos "interpela" ou "solicita" - mas de tal sorte que essa "saudade" ou "nostalgia", essa "tensão" ou "pulsão", etc., têm como "objecto" o mundo no seu todo e visam constituir o mundo no seu todo enquanto "casa". 5

4 GA 29/30 7.

5 Já Marco Aurélio se havia referido a esta "pulsão" para "em toda a parte estar no mundo como em casa" enquanto "propriedade" fundamental da vivência da filosofia

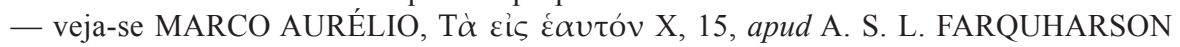

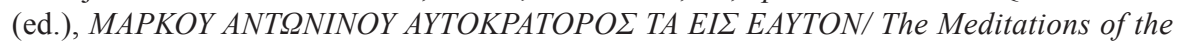
Emperor Marcus Antoninus (With Translation and Commentary), vol. I (Text and Transla-

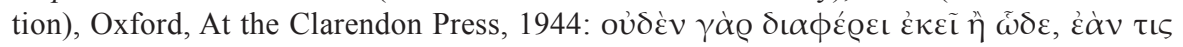

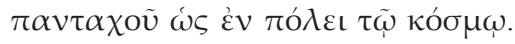


Mas - como Heidegger refere - a "saudade" ou "nostalgia" do mundo como "casa" (a "tensão" ou "pulsão" para a constituição do mundo como um "lugar" "habitável" e "acolhedor", etc.) pressupõe um facto fundamental que parece caracterizar de raiz a filosofia e definir a situação em que a filosofia se acha, a saber: o facto de a filosofia estar no mundo como "fora de casa" (como num "lugar" "inabitável" e "inóspito"): como numa situação de "exílio" (como "longe da pátria" a que pertence e a que quer "regressar"). ${ }^{6}$

A filosofia - pelo menos tal como Heidegger o indica em GA 29/30 corresponde assim a uma "saudade" ou "nostalgia" do mundo como "casa", a uma "tensão" ou "pulsão" para constituir o mundo como "casa" (se assim se pode dizer: como "casa total"); pois a filosofia acha-se precisamente numa situação de "exílio" e "inospitalidade"7 no próprio mundo que procura constituir como "casa (total)".

Segundo Heidegger, a existência humana (a transcendência do Umwillen seiner que caracteriza o acontecimento do Dasein no ser humano) acha-se constituída de raiz por meio de uma relação fundamental de "interesse" com a totalidade do si mesmo a haver, com a totalidade das possibilidades "majorantes" do si mesmo ainda a haver. ${ }^{8}$

Para Heidegger, além disso, o "interesse" fundamental do Dasein pela totalidade em questão equivale a um "interesse" fundamental pela totalidade de si mesmo (e tanto quer dizer: pela totalidade do mundo).

Mas não sucede apenas que - segundo a constituição fundamental da existência humana - o si mesmo está em causa para si mesmo e se acha por natureza numa relação com a totalidade de si mesmo ainda a haver (numa relação com a totalidade do mundo). Pois sucede também que a condição fundamental da existência assim constituída se caracteriza pela solidão: pela "distância" ou "saudade" do si mesmo em relação a si mesmo enquanto totalidade de si mesmo ainda a haver (enquanto totalidade do mundo).

Com efeito, a totalidade do si mesmo ainda a haver (a totalidade do mundo) é aquilo por cuja "ausência" ou por cuja "distância" a existência humana se pode definir como uma existência solitária; a totalidade do si mesmo ainda a haver (a totalidade do mundo) é o "outro" de si mesmo (a alteridade do si mesmo em relação a si mesmo: aquilo que o si mesmo ainda não "possui" de si mesmo) por "contacto" com o qual se pode constituir a solidão enquanto

6 Sobre a filosofia e a existência humana como "viagens de regresso", veja-se P. A. LIMA, Heidegger e a fenomenologia da solidão humana (Tese de Doutoramento apresentada à Faculdade de Ciências Sociais e Humanas da Universidade Nova de Lisboa), vol. I, Lisboa, 2012, pp. 89-93 (sobretudo a nota 32).

7 A respeito do fenómeno da inospitalidade, veja-se IDEM, op. cit., vol. II, pp. 775-842 .

8 A propósito da transcendência do Umwillen seiner, veja-se ibid., pp. 935-1004. 
"saudade" ou "distância" do si mesmo em relação a si mesmo (a Einsamkeit enquanto Heimweh - Sehnsucht - ou Ferne).

Numa palavra: tanto a caracterização da filosofia como "saudade" — em GA 29/30 — quanto a determinação da existência humana como solitária a partir de Was ist Metaphysik? e de Vom Wesen des Grundes $^{9}$ - apontam para a condição "intermédia" (para a condição de $\mu \varepsilon \tau \alpha \xi u ́$ ou para a condição de $\delta \alpha i ́ \mu \omega v$ : como diz Platão por exemplo no discurso de Sócrates/ Diotima no Symposium) daquilo que em cada caso está a ser considerado: a filosofia ou a existência humana. ${ }^{10}$

Dito de outro modo: quer na caracterização da filosofia como "saudade" quer na determinação da existência humana como solitária está em causa o reconhecimento da natureza finita do que em cada caso se acha sob foco: está em causa o reconhecimento da natureza finita da filosofia ou da existência humana - o reconhecimento da finitude radical que torna tanto a filosofia quanto a existência humana em acontecimentos fundamentalmente marcados pela condição "intermédia" (pela condição de $\delta \alpha i ́ \mu \omega v$ ) de que se falou. ${ }^{11}$

Ora, quer a filosofia quer a existência humana estão marcadas pela condição "intermédia" na medida em que se caracterizam por uma "saudade" fundamental da - por uma "pulsão" fundamental para a — totalidade do si mesmo a haver.

Mas isso de tal modo que se, por um lado, se acham ambas já "a caminho" desta totalidade ("em trânsito" para esta totalidade), por outro lado, define-as ao mesmo tempo a circunstância de a totalidade para que já "caminham" (a totalidade para que já se acham "em trânsito") ser algo que ainda não "alcançaram": algo de que ainda estão "afastadas" ou de que ainda estão "privadas" (algo que ainda não "possuem" ou que ainda não são de forma plena).

Segundo Heidegger, é esta peculiar modalidade de finitude que caracteriza a filosofia e a existência humana. Trata-se de uma modalidade de finitude

9 Sobre a "distância" do si mesmo em relação a si mesmo e o "outro" de si mesmo por cuja "ausência" se constitui a solidão (tal como ambos os temas se acham tratados em Was ist Metaphysik? e Vom Wesen des Grundes), veja-se ibid.

10 A respeito das noções de $\mu \varepsilon \tau \alpha \xi u ́$ e de $\delta \alpha i ́ \mu \omega v$, veja-se M. J. CARVALHO, "Do Belo como constituinte do Humano segundo Sócrates/ Diotima", Revista filosófica de Co-

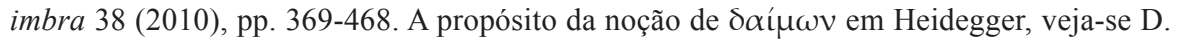
F. KRELL, Daimon Life: Heidegger and Life-Philosophy, Bloomington and Indianapolis, Indiana University Press, 1992.

11 Quanto ao problema da finitude do ponto de vista humano, vejam-se as incontornáveis investigações de M. J. CARVALHO, Problemas fundamentais de fenomenologia da finitude (Tese de Doutoramento apresentada à Faculdade de Ciências Sociais e Humanas da Universidade Nova de Lisboa), 3 vols., Lisboa, 1996. 
em virtude da qual quer a filosofia quer a existência humana se definem como Heidegger diz - por uma "oscilação" do seu termo fundamental de relação (que ora é a situação de facto em que já se encontram ora é aquilo para que nessa situação sempre já "tendem"); por terem a condição de um "nem uma coisa nem a outra" (a condição de algo que não é propriamente só a situação de facto em que já está nem é plenamente a totalidade para que sempre já "tende" e de que sempre já "sente saudade"); por aquela forma de "inquietação" que só parece achar "repouso" uma vez "alcançada" (uma vez plenamente realizada) a totalidade das possibilidades "majorantes" do si mesmo a haver (aquilo que mais propriamente constitui a totalidade do mundo):

"Dahin, zum Sein im Ganzen sind wir in unserem Heimweh getrieben. Unser Sein ist diese Getriebenheit. Wir sind immer schon irgendwie zu diesem Ganzen fortgegangen oder besser unterwegs dazu. Aber wir sind angetrieben, d.h. wir sind zugleich irgendwie von etwas zurückgerissen, in einer abziehenden Schwere ruhend. Wir sind unterwegs zu diesem im Ganzen $<$. Wir sind selbst dieses Unterwegs, dieser Übergang, dieses >Weder das Eine noch das Andere`. Was ist dieses Hin- und Herschwingen zwischen dem Weder-Noch? Nicht das Eine und ebenso nicht das Andere, dieses >Doch und doch nicht und doch ist diese Unruhe des Nicht? Wir nennen es die Endlichkeit." 12

O paralelo que estamos a fazer entre a determinação da existência humana como solitária e a caracterização da filosofia como "saudade" acha-se legitimado não só pelo facto de - como acabámos de ver — quer a existência humana quer a filosofia se deixarem definir como "solidão" ou "saudade" do si mesmo em relação a si mesmo, mas também pela circunstância de - como o passo que citamos em seguida mostra com clareza - Heidegger se referir à filosofia como um "processo" de "finitização" e de isolamento (=nomen actionis) do Dasein. Trata-se de um "processo" pelo qual o Dasein se pode tornar (e manter) consciente da "distância" de si mesmo em relação a si mesmo. É a consciência desta "distância" que o constitui que permite ao Dasein ter uma relação "transparente" ao "essencial" daquilo que encontra na esfera da proximidade:

"Endlichkeit ist keine Eigenschaft, die uns nur anhängt, sondern die Grundart unseres Seins. Wenn wir werden wollen, was wir sind, können wir diese Endlichkeit nicht verlassen oder uns darüber täuschen, sondern wir müssen sie behüten. Dieses Bewahren ist der innerste Prozeß unseres Endlichseins, d.h. unsere innerste Verendlichung. Endlichkeit ist nur in der wahren Verendlichung. In dieser aber vollzieht sich letztlich eine Vereinzelung des Menschen auf sein Dasein. Vereinzelung — das meint nicht dieses, daß der Mensch sich auf sein

12 GA 29/30 8. 
schmächtiges und kleines Ich versteift, das sich aufspreizt an diesem oder jenem, was es für die Welt hält. Diese Vereinzelung ist vielmehr jene Vereinsamung, in der jeder Mensch allererst in die Nähe zum Wesentlichen aller Dinge gelangt, zur Welt."13

Mas - apesar do paralelo que tentámos estabelecer — sucede que até aqui a caracterização da filosofia como "saudade" e a caracterização da existência humana como solitária não passaram justamente de caracterizações paralelas, quer dizer: de caracterizações que - se alcançaram os mesmos resultados no que diz respeito àquilo que em cada caso se achava sob foco (se concluíram que quer a filosofia quer a existência humana se podem definir como "saudade" do si mesmo em relação a si mesmo e como duas formas de acontecimento marcadas por solidão) - não serviram (pelo menos à partida e declaradamente) para caracterizar a mesma forma de acontecimento.

Numa palavra: na análise de Heidegger - tal como a apresentámos até agora - a filosofia e a existência humana (enquanto acontecimentos de solidão e de "saudade" do si em relação a si) não parecem ser o mesmo, não parecem partilhar a mesma estrutura fundamental. De tal sorte que a solidão e a "saudade" que - segundo Heidegger - definem à vez a filosofia e a existência humana não parecem referir o mesmo fenómeno: mas fenómenos diferentes (solidões e "saudades" diferentes) por ser diferente a estrutura fundamental a que em cada caso dizem respeito.

Ora, no que se segue não procuraremos produzir apenas a inflexão de perspectiva segundo a qual a solidão (enquanto "saudade" ou "distância" de si mesmo em relação a si mesmo: a Einsamkeit) se passa a "assumir" como a condição da filosofia e do "ponto de vista" que corresponde à filosofia, mas também a inflexão de perspectiva nos termos da qual a filosofia (a solidão: a "saudade" ou a "distância" que a caracteriza) representa o "contacto" transparente da existência humana consigo mesma (com a solidão: com a "saudade ou a "distância" que caracteriza a solidão e constitui a existência humana).

Pois - como Heidegger diz - a filosofia não corresponde a algo à parte da existência humana, antes equivale à "actividade" que o ser humano enquanto tal de algum modo sempre já executa:

"Philosophie - eine letzte Aussprache und Zwiesprache des Menschen, die ihn ganz und ständig durchgreift. Aber was ist der Mensch, daß er im Grunde seines Wesens philosophiert, und was ist dieses Philosophieren? Was sind wir dabei? Wohin wollen wir?"14

13 GA 29/30 8.

14 GA 29/30 7. 
Isso significa que - no que procuraremos fazer até ao final do presente estudo - será posto em destaque que as solidões e as "saudades" que para Heidegger definem a filosofia e a existência humana não são diferentes mas as mesmas: são uma e a mesma solidão, uma e a mesma "saudade".

Tentaremos além disso pôr em evidência o seguinte: porque a filosofia (a solidão: a "saudade" ou a "distância" que caracteriza a filosofia e a perspectiva que corresponde à filosofia) representa a relação transparente da existência humana consigo mesma, a solidão - enquanto Einsamkeit ${ }^{15}$ - exprime a condição tanto da existência humana quanto da perspectiva a partir da qual a existência humana se relaciona de modo transparente consigo mesma.

\section{Saudade e disposição (Stimmung)}

Dito isto, importa agora aprofundar um pouco o significado da "saudade" (Heimweh) que - de acordo com Heidegger - define a filosofia e a existência humana enquanto tais.

Ora, para Heidegger a "saudade" (Heimweh) é uma forma de "disposição" (Stimmung): a "disposição fundamental" (Grundstimmung) da existência humana e assim também da filosofia (na qual a existência humana é "posta diante" de si mesma de modo transparente e sem dissimulação).

Este é um dado que nos deve levar a rever (sucintamente) aquilo que já dissemos.

Assim, é todo o entendimento do acontecimento do Dasein no ser humano - é toda a relação do Dasein consigo mesmo e com o mundo (com a totalidade de si mesmo a haver, com a totalidade das possibilidades de si mesmo ainda a realizar) - que tem de ser revisto à luz da compreensão da "saudade" como disposição fundamental da filosofia e da existência humana.

Pois, vendo bem, se a "saudade" é uma disposição, então - na medida em que a "saudade" define (segundo Heidegger) a tensão existencial enquanto tal e determina o "aspecto" de tudo quanto aparece no horizonte de manifestação "aberto" por essa tensão — é numa disposição (na disposição fundamental da "saudade") que assenta toda a relação do Dasein consigo mesmo (toda a tensão existencial enquanto tal) e com tudo quanto aparece no horizonte de manifestação do mundo.

15 Heidegger desenvolve uma fenomenologia da solidão que não se limita a focar a Einsamkeit (que é apenas uma das formas de solidão). A respeito de outras formas de solidão na obra de Heidegger (tais como o Alleinsein e a existenziale Vereinzelung em sentido estrito), veja-se P. A. LIMA, op. cit., vol. II, pp. 437-919. Para uma distinção terminológica entre Alleinsein, Vereinzelung e Einsamkeit, veja-se ibid., pp. 928-929 (nota 596). 
Mais do que isso: se a "saudade" é uma disposição, então — uma vez que a "saudade" exprime a relação constitutiva do Dasein com a totalidade de si mesmo a haver enquanto totalidade que ainda não é plenamente (dito de outro modo: uma vez que a "saudade" exprime a condição solitária da existência humana) - é numa disposição (na disposição fundamental da "saudade") que assenta o auto-reconhecimento do Dasein (o auto-reconhecimento do si mesmo que "arrosta" com o $D a$ ) como algo que ainda não é plenamente: como algo só e, pelo menos ainda, "sem si mesmo".

E se a "saudade" designa não apenas a condição de se estar só (o facto de tudo quanto há ser a manifestação da solidão do próprio horizonte em que aparece), mas também a "pulsão" (Trieb) para superar essa condição solitária (para alcançar aquilo que se acha "ausente" e de que se "sente saudade"), então é numa disposição que assenta não apenas a condição solitária que se tem, mas também a própria "pulsão" para se deixar de estar só. Aliás, segundo Heidegger a "pulsão" em causa e a própria forma de "obtenção" daquilo para que nela se "tende" são disposições (têm um carácter fundamentalmente disposicional).

A natureza disposicional da filosofia e da existência humana enquanto acontecimentos de solidão é da maior importância para se compreender o modo como - segundo Heidegger - sempre já se está na filosofia e sempre já se existe numa "saudade" de si mesmo e numa "pulsão" para "satisfazer" essa "saudade" com a "presença" do que falta.

Mais: se não se tiver noção de que a filosofia e a existência humana (enquanto acontecimentos de solidão ou de "saudade" do si mesmo em relação a si mesmo) são de natureza disposicional, não se pode perceber adequadamente como "se dá" na existência humana a "revelação" desta como filosófica e como solitária.

Pois - se virmos bem - é a constituição disposicional da existência humana (é o facto de a existência humana se achar constituída numa "passividade" fundamental que a "expõe" totalmente a modos de "revelação" do seu próprio sentido que não podem ser "controlados" ou determinados pela reflexão voluntária de que se dispõe) que faz que a conceptualidade da filosofia - a conceptualidade da própria existência — seja de natureza fundamentalmente "passiva", se constitua como "reacção" à circunstância de a existência já ter sido "tocada" ou "afectada" ("apanhada" ou "agarrada") por algo, pela disposição da "saudade" ou da solidão:

"Philosophie geschieht je in einer Grundstimmung. Philosophisches Begreifen gründet in einer Ergriffenheit und diese in einer Grundstimmung. Meint nicht Novalis am Ende so etwas, wenn er die Philosophie ein Heimweh nennt?"16

16 GA 29/30 10. 
Mas detenhamo-nos um pouco nesta questão. Pois a situação hermenêutica de que Heidegger parte é bastante peculiar e da sua adequada "restituição" depende a compreensão do modo como a disposição fundamental da solidão ou da "saudade" do si mesmo em relação a si mesmo "afecta" a existência humana; e disso depende também a compreensão de como a existência humana (por meio da filosofia enquanto "contacto" transparente da existência humana consigo mesma) "reage" a essa "afectação".

Assim, as análises de Heidegger - que temos estado a considerar - sobre a filosofia e a existência humana (enquanto formas de solidão ou de "saudade" do si mesmo em relação a si mesmo) tomam como ponto de partida o fragmento de Novalis há pouco citado.

Isso significa que — pelo menos no caso de GA 29/30 — a tese de que a filosofia é solidão ou "saudade" do si mesmo em relação a si mesmo equivale a uma tese de que se tem "notícia" a partir do contacto (ou do confronto) com a tradição ocidental, da qual Novalis faz parte.

Trata-se portanto de uma tese que está "disponível" para nós, que pode ser "retomada" por nós e que nós podemos utilizar como ponto de partida para a definição da situação em que nos encontramos.

O modo como Heidegger - em GA 29/30 - entra em contacto com a tese de que a filosofia é solidão ou "saudade" do si mesmo em relação a si mesmo (designadamente: a partir da leitura de um fragmento de Novalis) dá pois testemunho de que a filosofia - o esforço de obtenção de uma relação transparente da existência humana consigo mesma - é uma possibilidade herdada culturalmente: no sentido em que a nossa formação cultural nos pode levar ao contacto com a filosofia e no sentido em que a filosofia nos pode então "afectar" na compreensão global que temos da existência que é a nossa.

Mas - importa notar - o contacto com a filosofia (o sermos "afectados" pela filosofia) não é o contacto com (o sermos "afectados" por) uma possibilidade induzida do exterior: antes corresponde ao contacto com (ao sermos "afectados" por) uma possibilidade que diz respeito ao "mais íntimo" de cada um de nós. Trata-se da possibilidade de nos descobrirmos a nós mesmos na constituição fundamental que temos e que sempre já se acha inexplicitamente "na base" da existência que levamos.

Ora, é isso que se passa no que diz respeito à tese de que a existência humana e a filosofia (quer dizer: o esforço de obtenção de uma relação transparente da existência humana consigo mesma) - enquanto tais - são solidão ou "saudade" do si mesmo em relação a si mesmo.

Não se trata - como dissemos — de uma possibilidade induzida do exterior, mas de uma possibilidade nossa: uma possibilidade que podemos resolver explorar como algo que nos diz respeito e que podemos resolver 
examinar na capacidade que tem para prestar esclarecimentos sobre a constituição fundamental do nosso modo de ser próprio.

Mas - por outro lado - trata-se de uma possibilidade que (por mais que já tenha sido examinada enquanto possibilidade própria) permanece sempre por explorar e tende permanentemente a "cair" num certo esquecimento do seu significado.

De sorte que se tem de perseverar no esforço de patenteação de tal possibilidade. Só assim é possível evitar que o seu significado "caia" em esquecimento ou se torne obscuro para nós. Pois - como Heidegger refere - a possibilidade em questão (a possibilidade de a filosofia e a existência serem solidão ou "saudade" do si mesmo em relação a si mesmo) tende a "regressar" ao "lugar" de onde "emerge" (isto é: tende a "regressar" ao "núcleo" - o mais das vezes indetectado - do próprio ser humano enquanto tal):

"Dieses Dabeibleiben ist die besondere Schwierigkeit, zumal deshalb, weil die Philosophie, sobald wir ihr selbst ernsthaft nachfragen, sich uns in ein eigentümliches Dunkel entzieht, dahin, wo sie eigentlich ist: als menschliches Tun im Grunde des Wesens des menschlichen Daseins."17

Portanto, independentemente de já se estar ou não num esforço de constituição de uma relação explícita e transparente com a existência própria, o encontro ou o confronto com os textos de outrem - com os textos que formam a tradição - representa uma possibilidade de apercepção de aprofundamento e de insistência na patenteação - daquilo que de raiz nos faz.

Trata-se - por outras palavras — de um encontro ou de um confronto que pode provocar a "afectação" disposicional de que falámos há pouco: a "afectação" disposicional que "precede" e motiva a própria "reacção conceptual" da filosofia.

Podemos dizer - com Heidegger - que os conceitos filosóficos se caracterizam sobretudo pelo facto de "implicarem" (no que neles está em causa captar) aquele que procura captar: aquele que procura captar aquilo que o constitui no seu próprio ser e aquilo que define a própria situação em que se acha.

Ora, porque o alcance dos conceitos filosóficos é - segundo Heidegger - total (de tal modo que "atravessam" e "implicam" a totalidade da existência humana), o alcance da filosofia também é total. O que a filosofia tenta captar é, pois, a totalidade da situação em que se acha: a totalidade da existência de que faz parte e de que é expressão. Noutros termos, a filosofia

17 GA 29/30 11. 
corresponde ao processo de auto-esclarecimento da existência humana (da totalidade com que a existência humana sempre já se acha em "contacto"):

"Sie [die Grundbegriffe der Metaphysik] begreifen je das Ganze in sich, sie sind In-begriffe. Aber sie sind Inbegriffe noch in einem zweiten, ebenso wesentlichen und mit dem ersten zusammenhängenden Sinne: Sie begreifen je immer den begreifenden Menschen und sein Dasein mit in sich — nicht nachträglich, sondern so, daß sie nicht jenes sind ohne dieses, und umgekehrt. Kein Begriff des Ganzen ohne Inbegriff der philosophierenden Existenz. Metaphysisches Denken ist inbegriffliches Denken in diesem doppelten Sinne: auf das Ganze gehend und die Existenz durchgreifend."18

"Metaphysik ist ein Fragen, in dem wir in das Ganze des Seienden hineinfragen und so fragen, daß wir selbst, die Fragenden, dabei mit in die Frage gestellt, in Frage gestellt werden."19

Mas não nos esqueçamos de que o que aqui está em causa é a tese de que a filosofia e a existência humana são solidão ou "saudade" do si mesmo em relação a si mesmo.

É isso que - como vimos - se acha expresso no fragmento de Novalis em que Heidegger se "inspira"; e é também isso que aqui tem de ser posto à prova na sua capacidade para dar conta da situação em que se está enquanto situação "marcada" por solidão: por "saudade" do si mesmo em relação a si mesmo.

Noutros termos: está em causa o problema da definição (ou do esclarecimento) da própria situação em que nos achamos. ${ }^{20}$ Mas de tal modo que esse problema de definição (ou de esclarecimento) é objecto de revisão por parte de Heidegger em GA 29/30. Segundo Heidegger, a situação em que nos achamos - e que se trata de definir (ou de esclarecer) - está "de antemão" "reconhecida" como situação "marcada" por solidão: por "saudade" do si mesmo em relação a si mesmo.

O que se trata de definir (ou de esclarecer) é, então: que solidão ou "saudade" do si mesmo em relação a si mesmo - do si mesmo em relação à totalidade de si mesmo ainda a haver (do si mesmo em relação ao mundo) —é aquela em que nos encontramos?

Para Heidegger, um passo importante a dar é o da "evocação" da própria solidão ou "saudade" em que (explícita ou inexplicitamente) sempre já se está. Trata-se pois de procurar que essa solidão ou "saudade" venha a uma "presença explícita" e possa "afectar expressamente" a situação em que se

18 GA 29/30 13.

19 GA 29/30 13.

20 Sobre o problema da definição da situação em que se está (tal como é considerado na fenomenologia de Heidegger), veja-se P. A. LIMA, op. cit., vol. I, pp. 73-136. 
está. "Expressamente afectado" por tal solidão ou "saudade", cada ser humano - cada um de nós - pode passar a perguntar pelo próprio sentido daquilo em relação ao qual se acha só ou daquilo de que tem "saudade" (isto é: pode passar a perguntar pelo próprio sentido do mundo).

De acordo com Heidegger, essa pergunta corresponde à actividade própria da filosofia — à actividade que também designa como a "finitização" ou o isolamento (=nomen actionis) do ser humano:

"Es ergab sich dabei, daß dieses Verlangen, überall zu Hause zu sein, das heißt im Ganzen des Seienden zu existieren, nichts anderes als ein eigentümliches Fragen nach dem ist, was dieses sim Ganzen<, das wir Welt nennen, besagt. Was da in diesem Fragen und Suchen, in diesem Hin-und-her geschieht, ist die Endlichkeit des Menschen. Was sich in dieser Verendlichung vollzieht, ist eine letzte Vereinsamung des Menschen, in der jeder für sich wie ein Einziger vor dem Ganzen steht."21

Há portanto uma determinada desformalização do problema da definição ou do esclarecimento da filosofia (da situação em que se está enquanto se encontra sempre já "marcada" pela filosofia). Trata-se da desformalização nos termos da qual o problema em causa é já o da definição ou o do esclarecimento da situação em que se está (o da definição ou o do esclarecimento da filosofia) enquanto solidão ou "saudade" do si mesmo em relação a si mesmo.

Ora, enquanto solidão ou "saudade" do si mesmo em relação a si mesmo, a situação em que se está e que tem de ser definida ou esclarecida - a filosofia como actividade fundamental do ser humano - tem um carácter disposicional.

De sorte que a "evocação" da solidão ou "saudade" em que se está (e que na filosofia se trata de definir ou esclarecer) corresponde à "evocação" de uma disposição fundamental.

Tal disposição é fundamental porque se acha "na base" quer da filosofia quer da existência em geral e também porque se acha sempre já - explícita ou inexplicitamente - a determinar o modo como se é:

"Es gilt nicht, diese Fragen [nach Welt, Endlichkeit und Einsamkeit] als theoretische zu entwickeln und eine Stimmung dazu und daneben hervorzubringen, sondern umgekehrt, wir müssen diese Fragen allererst aus einer Grundstimmung heraus in ihrer Notwendigkeit und Möglichkeit entstehen lassen und in ihrer Eigenständigkeit und Unzweideutigkeit zu bewahren suchen. Wir vollziehen demnach dieses Fragen eigentlich, wenn wir uns daran machen, eine Grundstimmung unseres Philosophierens zu wecken. Das ist die erste und eigentliche Grundaufgabe unserer Vorlesung und der Beginn eines wirklichen lebendigen Philosophierens." 22

21 GA 29/30 12.

22 GA 29/30 87. 


\section{Filosofia, saudade e tédio (Langeweile)}

Heidegger não "tematiza directamente" a solidão ou a "saudade" do si mesmo em relação a si mesmo; recorre, antes, à disposição fundamental do tédio profundo (a qual "identifica" com a "experiência" da solidão ou da "saudade" do si mesmo em relação a si mesmo). ${ }^{23}$

Heidegger procura além disso compreender a modalidade de tédio referida a partir da estrutura fundamental da temporalidade; o que significa que é também a partir dessa estrutura fundamental que tenta captar o fundamento e a condição de possibilidade da filosofia e da existência humana enquanto solidão ou "saudade" do si mesmo em relação a si mesmo:

"Tiefe Langeweile - ein Heimweh. Heimweh, ein Heimweh — hörten wir irgendwo - sei das Philosophieren. Langeweile - eine Grundstimmung des Philosophierens. Langeweile — was ist sie?"24

"Wenn die Zeit mit der Langeweile zusammenhängt und andererseits irgendwie der Boden für die drei Fragen ist, dann macht die Grundstimmung der Langeweile ein ausgezeichnetes Zeitverhältnis im menschlichen Dasein und damit eine ausgezeichnete Möglichkeit aus, die drei Fragen [die Fragen nach Welt, Endlichkeit und Einsamkeit] zu beantworten." 25

Ora, Heidegger procura analisar o fenómeno do "tédio profundo" (tiefe Langeweile) em três momentos distintos, a saber, por meio da consideração:

1) da fórmula linguística es ist einem langweilig;

2) daquilo a que chama Leergelassenheit; e

3) daquilo que designa como Hingehaltenheit. ${ }^{26}$

23 A propósito do vocabulário do tédio em português, veja-se o interessante e "divertido" artigo de MIGUEL ESTEVES CARDOSO, "Tédio à portuguesa", Público - P2 (27/08/2010), pp. 4-5. Um belíssimo documento literário sobre o tédio como disposição da cultura europeia parece-nos ser GONÇALO M. TAVARES, Uma viagem à Índia, Alfragide, Editorial Caminho, 2010. Se é assim, então Gonçalo M. Tavares está em perfeita sintonia com Heidegger, que - por exemplo em GA 29/30 103-116 — fala do tédio como "uma disposição fundamental da nossa situação actual" (eine Grundstimmung unserer heutigen Lage).

24 GA 29/30 120.

25 GA 29/30 121.

26 Estamos cientes de que uma análise cabal do fenómeno do tédio — uma análise cujo propósito fundamental fosse o máximo esclarecimento do fenómeno do tédio enquanto tal (e não a exposição da Einsamkeit) —, antes mesmo de se debruçar sobre o tédio profundo teria de determinar as duas outras modalidades de tédio a que Heidegger se refere em GA 29/30 117-198. Mas, porque o nosso objectivo é apenas mostrar como é que o tédio profundo corresponde à modalidade de tédio que Heidegger "identifica" com o 


\section{O tédio profundo (es ist einem langweilig)}

Comecemos - como Heidegger - por ver o que é que está em causa na fórmula es ist einem langweilig (qual é o seu estatuto).

Além disso, vejamos que é que a fórmula em questão nos pode "revelar" sobre o tédio profundo e sobre a relação do tédio profundo com o fenómeno da solidão ou da "saudade" do si mesmo em relação a si mesmo.

Trata-se pois de uma fórmula de carácter linguístico, ou seja: de uma fórmula que - segundo Heidegger - exprime a própria "experiência" do tédio profundo.

Isso significa que na experiência do tédio profundo está - entre outras coisas - também em causa uma "experiência linguística". Quer dizer: o tédio profundo - na própria "experiência" em que consiste - está constituído também por meio de uma determinada forma de expressão (ou - se se quiser - por meio de uma determinada forma de compreensão).

Quando Heidegger, neste contexto, fala de linguagem, não está em causa, necessariamente, uma forma de linguagem expressa, uma determinada expressão que se pronuncia "em voz alta" para outrem escutar ou para nós próprios escutarmos.

Além disso, não está em questão, necessariamente, uma forma de linguagem que só se pronuncie "no silêncio" da relação que temos connosco, uma forma de linguagem que "deixe de parte" os outros com que também nos relacionamos.

Ambas as possibilidades - a possibilidade da expressão "em voz alta" e a da expressão "em silêncio" - são aceites por Heidegger como modos legítimos de exprimir genuinamente a experiência do tédio profundo (a compreensão "imanente" que lhe corresponde).

Assim, o fundamental (no que diz respeito à fórmula linguística em análise) é que - expressa "em voz alta" ou "em silêncio" - exprime essencialmente a compreensão que se tem quando se "experimenta" "em sede própria" o tédio profundo (por outras palavras: exprime aquilo que — quando se experimenta o tédio profundo - "se sabe" ou "é dado a saber" e aquilo que determina a relação que se tem com o todo do ente):

"Die tiefe Langeweile langweilt dann, wenn wir sagen, oder besser, wenn wir es schweigend wissen: es ist einem langweilig." 27

acontecimento da própria filosofia, ficaremos pela análise do tédio profundo. Procuraremos considerar apenas os aspectos do tédio profundo que podem ser percebidos com clareza sem a análise das outras duas modalidades de tédio de que Heidegger também fala em GA 29/30. A consideração do tédio profundo produzida nestes "moldes" é — parece-nos - suficiente para o que aqui pretendemos levar a cabo.

27 GA 29/30 202. 
Este é então o enraizamento da expressão es ist einem langweilig.

Não se trata - pelo que acabamos de ver — de uma expressão "exterior" à própria "experiência" do tédio profundo; trata-se - pelo contrário — de uma expressão "imanente" a essa "experiência".

$\mathrm{E}$, nesse sentido, es ist einem langweilig é uma expressão de que (ao que tudo indica: com legitimidade) se pode fazer uso para melhor se compreender que é que está em causa no tédio profundo: a que "experiência" peculiar é que o tédio profundo efectivamente corresponde, que relação é que o tédio profundo tem com a solidão ou a "saudade" de si mesmo e que é que propriamente se "revela" nele.

$\mathrm{O}$ que a expressão es ist einem langweilig fundamentalmente põe em evidência é - vendo bem -

a) o carácter anónimo daquele a quem o tédio profundo acontece e

b) o carácter involuntário (e também anónimo) da própria forma de acontecimento a que o tédio profundo corresponde. ${ }^{28}$

O carácter anónimo daquele que experimenta o tédio profundo vem na fórmula em análise - expresso pelo pronome impessoal einem.

Heidegger procura esclarecer o sentido do pronome referido (o sentido daquilo que esse pronome procura designar) por via de um contraste entre o sujeito humano - tal como espontaneamente o concebemos - e aquilo que a "experiência" do tédio profundo "revela" sobre esse sujeito: aquilo em que a "experiência" do tédio profundo verdadeiramente "depõe" como o mais próprio desse sujeito.

Heidegger diz que a "experiência" do tédio profundo "revela" ao sujeito humano a quem acontece que o que mais propriamente o constitui é diferente daquilo com que mais imediatamente se tende a identificar: o nome, a profissão, a idade, etc., etc.

Por outras palavras: no tédio profundo o sujeito humano "perde as referências habituais" de identificação de si mesmo. O sujeito humano "revela-se" então a si mesmo como algo "diferente" daquilo que julgara ser. Mas de tal modo que não se passa a identificar com outra "coisa", antes passa a "aparecer" a si mesmo como "mistério" ou "incógnita" (como "algo" sem identidade determinada: "algo" anónimo):

"Es - einem - nicht mir als mir, nicht dir als dir, nicht uns als uns, sondern einem. Name, Stand, Beruf, Rolle, Alter und Geschick als das Meinige und

28 Es ist einem langweilig é uma expressão paralela a es ist einem unheimlich. Também nesta expressão estão em causa o carácter anónimo daquele que a "profere", bem como o carácter involuntário e anónimo do fenómeno a que a expressão se "refere" (a saber: o fenómeno da angústia). A propósito de tudo isto, veja-se P. A. LIMA, op. cit., vol. II, pp. 925-1004. 
Deinige fällt von uns ab. Deutlicher, gerade dieses >es ist einem langweilig< läßt all das abfallen." 29

Mas - como dissemos - a fórmula es ist einem langweilig chama a atenção para um outro aspecto decisivo: e esse aspecto tem que ver com a natureza involuntária e anónima da "experiência" do tédio profundo.

Segundo Heidegger, com efeito, a "experiência" do tédio profundo é anónima: não só no sentido que acabámos de considerar (ou seja: não só no sentido em que o sujeito - que "sofre" a "experiência" do tédio profundo "aparece" a si mesmo como alguém sem identidade definida), mas também no sentido em que não se percebe bem que é que propriamente "motiva" o tédio profundo que "se sente".

O tédio profundo - segundo a fórmula sob foco - é algo que acontece e se verifica no seu facto: é algo em relação ao qual se tem o acesso limitado à verificação de que "é assim" como o tédio profundo "mostra" que é.

Ora, o aspecto relativo à natureza involuntária do tédio profundo está em estreita conexão com a natureza anónima que o tédio profundo também tem, uma vez que o facto de o tédio profundo ter lugar "à revelia" do sujeito a quem acontece implica que o sujeito que "sofre" a "experiência" do tédio profundo a "sofre" como algo que não sabe "de onde" provém e a que por isso mesmo não pode "resistir" ou "fazer frente".

A focagem da natureza involuntária do tédio profundo - por parte de Heidegger - não pode ser percebida de modo adequado se não se referir que o sujeito (a quem o tédio profundo acontece) tende habitualmente a "resistir" a "ficar tomado" por qualquer espécie de disposição que o faça "perder o controlo" da situação em que se acha: por qualquer espécie de disposição que o faça "perder" a "leveza" e a "segurança" que o mais das vezes caracteriza a sua forma de existir.

O tédio profundo, porém, emerge de um "lugar" de tal modo "fora do controlo" do sujeito que este é - como Heidegger refere - "forçado a escutar" (Gezwungensein zu einem Hören $)^{30}$; e, vendo bem, é "forçado a escutar" o sentido da própria fórmula em análise: es ist einem langweilig.

\section{A Leergelassenheit do tédio profundo (a Gleichgültigkeit)}

Como dissemos, Heidegger não analisa o fenómeno do tédio profundo apenas a partir da expressão es ist einem langweilig; analisa-o também por via do esclarecimento de duas das suas estruturas fundamentais: a Leergelassenheit e a Hingehaltenheit.

29 GA 29/30 203.

30 GA 29/30 205-206. 
Cabe-nos agora considerar a primeira destas duas estruturas: a Leergelassenheit do tédio profundo.

A bem dizer, nem a Leergelassenheit nem a Hingehaltenheit do tédio profundo podem ser separadas da fórmula que acima sucintamente considerámos. Pois, vendo bem, a Leergelassenheit e a Hingehaltenheit resultam de uma exploração, por parte de Heidegger, da última componente da fórmula es ist einem langweilig que ainda falta considerar: o adjectivo langweilig.

$\mathrm{Na}$ verdade, se já aqui considerámos o carácter anónimo daquele a quem o tédio profundo acontece, bem como a natureza anónima e involuntária da própria forma de acontecimento do tédio profundo, falta-nos ainda determinar o que é propriamente o tédio profundo: o que é isso que "revela" o próprio sujeito a si mesmo como uma verdadeira "incógnita", o que é isso que sucede não se sabe "de onde" nem como (e totalmente "à revelia" do sujeito a quem acontece).

Para esse efeito vamos começar por analisar a Leergelassenheit do tédio profundo.

A noção de Leergelassenheit - aplicada ao tédio profundo — procura expressar a peculiar forma de "desocupação de si" que resulta do fenómeno em questão.

Leergelassenheit - enquanto substantivo formado a partir do particípio perfeito do verbo leer lassen (isto é: a partir de leer gelassen) — designa o "resultado" de um determinado acontecimento: o "estado" em que se fica "em resultado" desse acontecimento.

No caso particular da Leergelassenheit do tédio profundo, o acontecimento em questão é o tédio profundo, o qual "afecta" de tal modo o sujeito a quem acontece que o deixa "desocupado": sem "emprego de si mesmo".

Heidegger refere-se a esta "desocupação de si mesmo" - a esta "ausência de emprego de si mesmo" - usando o termo "indiferença" (Gleichgültigkeit). ${ }^{31}$

31 A "indiferença" (Gleichgültigkeit) do "tédio profundo" (tiefe Langeweile) é brilhantemente analisada por J.-L. MARION, Réduction et donation: Recherches sur Husserl, Heidegger et la phénoménologie, Paris, Presses Universitaires de France, 2004, pp. 249-302. Para Marion, trata-se de um fenómeno a partir do qual se pode compreender aquilo a que chama a "terceira redução" (troisième réduction) — a este propósito vejam-se também os seguintes textos: IDEM, Étant donné: Essai d'une phénoménologie de la donation, Paris, Presses Universitaires de France, 1997, troisième édition corrigée 2005, IDEM, "Remarques sur les origines de la Gegebenheit dans la pensée de Heidegger", Heidegger Studies 24 (2008), pp. 167-179, IDEM, "Die Wiederaufnahme der Gegebenheit durch Husserl und Heidegger”, in G. FIGAL, H.-H. GANDER (eds.), Heidegger und Husserl: Neue Perspektiven, Frankfurt am Main, Vittorio Klostermann, 2009, pp. 25-42. Quanto à indiferença do tédio profundo no pensamento de Heidegger, veja-se ainda P. A. LIMA, op. cit., vol. II, pp. 925-1004. 
O termo Gleichgültigkeit é formado a partir do adjectivo gleichgültig; refere-se, em particular, à "perda de valor" de algo para alguém, ou melhor: à "perda de valor" que torna algo indiferente ou irrelevante para alguém (que torna algo em algo sem relevo ou destaque: em algo "igual" a tudo o mais "mera paisagem").

Isto significa que - segundo Heidegger - o tédio profundo é um acontecimento em que algo se torna gleichgültig: indiferente e "igual" a tudo o mais. E significa também que o tédio profundo torna algo a tal ponto gleichgültig que o sujeito a quem o tédio profundo acontece "vê" ser "suspensa" a sua relação habitual de "interesse" por isso mesmo que lhe passa a "aparecer" como indiferente ou irrelevante.

Todavia, no tédio profundo aquilo que se torna gleichgültig - aquilo que se "vê" "afectado" pela Gleichgültigkeit — não é algo "avulso" (nem sequer é um determinado conjunto de coisas ou de acontecimentos, etc.).

Não: no tédio profundo o que se torna gleichgültig — o que se "vê" "afectado" pela Gleichgültigkeit — é aquilo a que Heidegger chama o "ente no seu todo" (das Seiende im Ganzen). ${ }^{32}$

Noutros termos: é o ente no seu todo - e não este ou aquele ente (este ou aquele conjunto de entes) - que se torna indiferente, destituído de qualquer espécie de relevância ao ponto de a relação de "interesse" do sujeito pelo todo do ente (a "ocupação" do sujeito com o todo do ente) se "ver" "quebrada", "desactivada":

"Die ganze Situation und wir selbst als dieses individuelle Subjekt sind dabei gleichgültig, ja diese Langeweile läßt es gerade nicht erst dazu kommen, daß dergleichen uns etwas Besonderes gilt, sie macht vielmehr, daß alles gleich viel und gleich wenig gilt. Was alles und wieviel gleich? Diese Langeweile nimmt uns gerade darauf zurück, daß wir nicht erst dieses und jenes Seiende und für uns in dieser bestimmten Situation suchen; sie nimmt uns darauf zurück, wo uns jedes mit jedem gleichgültig erscheint." ${ }^{\text {33 }}$

Como já se pode ver por meio do passo agora citado, não é só a relação de "interesse" do sujeito ou do si mesmo pelo todo do ente (pelo todo do ente que - em sentido estrito - é "diferente" do sujeito ou do si mesmo) que passa a ser gleichgültig, que passa a ficar "ferida" de Gleichgültigkeit.

Pois - em bom rigor - a própria relação de "interesse" do sujeito ou do si mesmo por si mesmo (quer dizer: a própria relação existencial do sujeito

32 Como Heidegger também diz, a Gleichgültigkeit "afecta" todo o ente "de uma só vez" (mit einem Schlage): "Und doch, alles Seiende, nicht dieses und jenes, steht in einer merkwürdigen Gleichgültigkeit, alles Seiende nicht in einem Nacheinander, sondern alles mit einem Schlage." (GA 29/30 209)

33 GA 29/30 207. 
ou do si mesmo consigo mesmo que está "na base" da sua relação com o demais) também se "manifesta" ao sujeito ou ao si mesmo como gleichgültig: como algo profundamente "afectado" por Gleichgültigkeit.

Ora, em última análise, é precisamente porque a relação de "interesse" do sujeito ou do si mesmo por si mesmo se torna indiferente para o próprio que a indiferença em causa se "alastra" ao demais ("infecta" ou "contamina" a relação do próprio com o demais).

Segundo Heidegger, o facto de o tédio profundo "afectar" de indiferença o todo do ente (e com isso a própria relação do si mesmo consigo mesmo) "mostra" justamente que o si mesmo de que se está a falar não corresponde a algo "separado" ou "excluído" do âmbito que equivale ao todo do ente. Pois - ao que tudo indica - nesse caso o si mesmo não seria minimamente "afectado" pela completa indiferença em que o tédio profundo parece "afundar" o ente no seu todo.

Para Heidegger, o tédio profundo "revela" como estrutura fundamental do si mesmo - ou do Dasein que constitui o si mesmo - aquilo a que chama estar "no meio do ente" (inmitten des Seienden).

Esta estrutura fundamental do si mesmo - ou do "aí de lucidez" que o constitui enquanto tal - procura exprimir uma multiplicidade de aspectos e o modo como esses aspectos se articulam entre si.

Em primeiro lugar, a estrutura em causa (estar "no meio do ente") procura exprimir o facto de o si mesmo - o "aí de lucidez" que o constitui — ser também ele um ente.

Mas, em segundo lugar, o si mesmo não constitui um ente desprovido de qualquer relação com os demais: um ente que ou não tem qualquer espécie de relação com os demais ou que - de todo o modo - não tem com eles uma relação de grande "significado" (uma relação de que - como quer que seja - dependa aquilo que o si mesmo é: o "sentido" fundamental do seu ser).

Pelo contrário, o si mesmo não só é um entre os entes (um ente que - a despeito da sua peculiaridade - está indespedivelmente entre os restantes), como aquilo que ele propriamente é se define por uma relação fundamental de "interesse" com os entes — com o todo do ente — "no meio" dos quais se acha.

E é de tal sorte assim que a forma como os entes "aparecem" ao si mesmo "influi" decisivamente no modo como o si se relaciona consigo.

$\mathrm{Ou}$ - inversamente - o modo como o si se relaciona consigo determina o "sentido" fundamental com que os restantes entes lhe "aparecem".

Ora, é justamente uma "ruptura" (ou uma "quebra") dessa relação fundamental (ou desse "elo" fundamental) entre o si mesmo e os restantes entes que o tédio profundo — tal como Heidegger o descreve em GA 29/30 — vem "operar". 
De acordo com o que acabamos de ver, o tédio profundo tem como resultado que o todo do ente (inclusivamente: o próprio si mesmo) fica "ferido" de - ou "afectado" por - Gleichgültigkeit. Ou seja: o tédio profundo tem como resultado que a relação de "interesse" do si mesmo por si mesmo e pelos restantes entes se passa a "revelar" como algo completamente gleichgültig.

Deste modo, é evidente que a relação de "interesse" do si mesmo por si mesmo (a qual - em última análise - é a relação que ao tornar-se gleichgültig parece "motivar" a Gleichgültigkeit da relação com das Seiende im Ganzen) - uma vez "suspensa" - "deixa" o si mesmo numa peculiar modalidade de solidão ou de "saudade".

Essa modalidade de solidão ou de "saudade" não consiste só no facto de o si mesmo perceber que se acha de cada vez constituído "à distância" da totalidade de si mesmo a haver; consiste também - e fundamentalmente - no facto de o próprio "empreendimento de si" (o próprio "interesse" pelo si mesmo a haver e a própria "tensão" para a sua realização plena) "se mostrar" ao si mesmo como irrelevante, "desprovido de valor", "vazio", inane.

É, com efeito, nessa modalidade de solidão ou de "saudade" — em virtude da qual o si mesmo se "vê" "privado" do próprio "interesse" por si mesmo a haver (e em virtude da qual o si mesmo "sente" a falta correspondente à "suspensão" da própria "tensão" para a realização plena da totalidade de si mesmo a haver) - que o tédio profundo "deixa" o si mesmo fáctico: o si mesmo que se acha "no meio do ente".

Mas tal não significa - como Heidegger refere e bem — que o todo do ente e toda a relação do si mesmo consigo mesmo deixem de existir.

Não: embora a relação de "interesse" fique "em suspenso" — deixe de se executar (e deixe de se executar na evidência com que habitualmente sempre já se executa) - , o que acontece é antes que (justamente por via dessa "suspensão") a relação de "interesse" - e aquilo a que de cada vez diz respeito, a saber: o "contacto" do si consigo e com o todo do ente - se passa a manifestar expressamente enquanto tal:

"Das Seiende ist — wie wir sagen — im Ganzen gleichgültig geworden, wir selbst als diese Personen nicht ausgenommen. Wir stehen nicht mehr als Subjekte und dergleichen ausgenommen von diesem Seienden diesem gegenüber, sondern finden uns inmitten des Seienden im Ganzen, d.h. im Ganzen dieser Gleichgültigkeit. Das Seiende im Ganzen verschwindet aber nicht, sondern zeigt sich gerade als solches in seiner Gleichgültigkeit. Die Leere besteht hier demgemäß in der Gleichgültigkeit, die im Ganzen das Seiende umfängt." ${ }^{4}$

34 GA 29/30 208. 
Por outras palavras, aquilo que fundamentalmente está em causa no tédio profundo é a anulação da "possibilidade de fazer ou deixar de fazer" (Möglichkeit des Tuns und Lassens) "algo" com o ente no seu todo, "algo" que tenha que ver com o "empreendimento de si", "algo" que dê um contributo para a realização plena de si mesmo a haver:

"Das Dasein findet sich durch diese Langeweile gerade vor das Seiende im Ganzen gestellt, sofern in dieser Langeweile das Seiende, das uns umgibt, keine Möglichkeit des Tuns und keine Möglichkeit des Lassens mehr bietet. Es versagt sich im Ganzen hinsichtlich dieser Möglichkeiten. Es versagt sich so einem Dasein, das als solches inmitten dieses Seienden im Ganzen zu ihm sich verhält — zu ihm, zum Seienden im Ganzen, das sich jetzt versagt — sich verhalten muß, wenn anders es sein soll als das, was es ist." ${ }^{35}$

\section{A Hingehaltenheit do tédio profundo (a Verweisung auf die brachlie- genden Möglichkeiten)}

Consideremos agora um último ponto sobre o fenómeno do tédio profundo: aquele que diz respeito à estrutura da Hingehaltenheit.

Tal como a estrutura da Leergelassenheit, assim também a estrutura da Hingehaltenheit do tédio profundo pode ser considerada como uma "etapa de exploração" do sentido da fórmula es ist einem langweilig.

Vejamos que é que significa Hingehaltenheit.

Hingehaltenheit é um substantivo formado a partir do particípio perfeito do verbo hinhalten. Hinhalten significa - entre outras coisas -: "demorar", "retardar", "protelar", etc. Mas, além disso, significa também: "estender", "apresentar", "oferecer", etc.

Estes parecem dois significados muito diferentes e à primeira vista inconciliáveis.

Todavia não é assim.

Como veremos de seguida, os dois significados em causa não só são perfeitamente conciliáveis, mas também contribuem para esclarecer os dois aspectos fundamentais do tédio profundo que se acham expressos pelo substantivo Hingehaltenheit.

De acordo com o que acabámos de considerar, Hingehaltenheit - na medida em que se trata de um substantivo formado a partir do particípio perfeito do verbo hinhalten - exprime o "estado" em que algo se acha "demorado", "retardado", "protelado", etc.

Isto por um lado.

35 GA 29/30 212. 
Por outro lado, se levarmos em conta o segundo significado que vimos que Hingehaltenheit também pode ter, Hingehaltenheit pode significar igualmente o "estado" em que algo se acha "estendido", "apresentado", "oferecido", etc.

Que é que isto quer dizer exactamente? Que é que isto pode ter que ver com o fenómeno do tédio profundo?

Pelo que já aqui dissemos, parece claro que a "experiência" do tédio profundo constitui uma "experiência" de "demora", "retardamento", "protelamento". E a "demora", o "retardamento", o "protelamento" em causa no tédio profundo dizem respeito justamente ao próprio curso do "empreendimento de si": ao próprio curso (ou à própria "fluência") da tensão existencial e do "estar embarcado" nela.

Assim, no que tem que ver com a "experiência" do tédio profundo, a noção de Hingehaltenheit exprime algo semelhante àquilo que já vimos que se acha referido pela noção de Leergelassenheit: a Gleichgültigkeit relativa ao próprio "empreendimento de si" (a qual acaba por "suspender" a "vigência" desse "empreendimento" e por tornar gleichgültig a relação com o todo do ente).

Heidegger chama claramente a atenção para este aspecto quando fala da Hingehaltenheit como um Hinweisen auf die brachliegenden Möglichkeiten:

"Dieses im Versagen selbst liegende Sagen, Hinweisen auf die brachliegenden Möglichkeiten, ist am Ende die zu dieser Leergelassenheit gehörige Hingehaltenheit." 36

Nesta explicitação, estão já indicados os dois aspectos que nos interessa destacar a respeito do tédio profundo.

Mas, para já, continuemos a considerar aquele aspecto que diz estritamente respeito à questão da "suspensão" da "vigência" do "empreendimento de si".

E esse aspecto acha-se consignado na expressão brachliegende Möglichkeiten.

Nesta expressão, parece claro que a noção de Möglichkeiten (no plural) faz referência à questão do "empreendimento de si", ou melhor: faz referência ao modo como o "empreendimento de si" se executa de cada vez pela adopção desta(s) ou daquela(s) possibilidade(s) enquanto meio(s) para a realização da plenitude do si mesmo a haver.

É, porém, no atributo brachliegend que vamos poder encontrar aquilo que - na expressão agora sob foco - reflecte a "propriedade" específica do tédio profundo.

36 GA 29/30 212. 
Com efeito, o adjectivo brachliegend designa "aquilo de que não se faz uso"; mas também "aquilo que é inútil"; etc.

Segundo esta caracterização, a expressão brachliegende Möglichkeiten refere "possibilidades de que não se faz uso", "possibilidades inúteis", etc.

Se não perdermos de vista que brachliegende Möglichkeiten é uma expressão que surge no contexto da caracterização do tédio profundo, percebe-se que o adjectivo brachliegend faz referência à "suspensão" da "vigência" do "empreendimento de si", quer dizer: faz referência à circunstância de as possibilidades por meio das quais o si executa o "empreendimento de si" estarem "feridas" de inutilidade — ou de Gleichgültigkeit — em virtude de a própria "vigência" do "empreendimento de si" se achar "em suspenso" (estar a ser vivida como algo inútil ou inteiramente gleichgültig).

Se o que vimos até aqui sobre a noção de Hingehaltenheit aplicada ao tédio profundo de algum modo já se achava consignado na noção de Leergelassenheit, a característica da Hingehaltenheit do tédio profundo que agora vamos passar a considerar introduz algo de novo, a saber: a noção de Hinweisen.

Heidegger também designa este fenómeno peculiar por meio da noção de Verweisung:

"Im Versagen liegt eine Verweisung auf anderes. Diese Verweisung ist das Ansagen der brachliegenden Möglichkeiten." ${ }^{37}$

Trata-se pois do Hinweisen (do Hinweisen auf... ou - como Heidegger também diz — da Verweisung auf...) relativo às brachliegende Möglichkeiten de que falámos.

No tédio profundo há, portanto, um Hinweisen auf... (uma Verweisung auf...) die brachliegenden Möglichkeiten.

A pergunta é, então: que é que tal propriamente significa? E, além disso: que é que tal tem que ver com o sentido de Hingehaltenheit (uma vez que a expressão Hinweisen auf die brachliegenden Möglichkeiten constitui como oportunamente referimos - uma explicitação do que se acha implicado na noção de Hingehaltenheit)?

Comecemos pela última questão.

O Hinweisen (a Verweisung) aqui em causa está ligado à noção de Hingehaltenheit enquanto esta significa o "estado" em que - o facto de que - algo se acha "estendido", "apresentado", "oferecido", etc. Por outras palavras, o Hinweisen (a Verweisung) aqui em causa designa um fenómeno de "apresentação" ou de "indicação": o fenómeno de uma "apresentação" ou de uma "indicação" em que algo nos é "estendido" ou "oferecido" (como quan-

37 GA 29/30 212. 
do dizemos que alguém "nos estende" a mão ou que alguém "nos oferece" alguma coisa, etc.).

Ora, na experiência do tédio profundo o que nos é "apresentado" ou "indicado" (o que nos é "estendido", "oferecido" ou — como também podemos dizer - "dado a ver") são justamente as Möglichkeiten de que falámos. Não, todavia, enquanto possibilidades "disponíveis" ("apropriáveis" no quadro da execução de um "empreendimento de si"), mas enquanto possibilidades "inúteis" no sentido acima referido (isto é: enquanto brachliegende Möglichkeiten ou - se se quiser - gleichgültige Möglichkeiten no sentido que temos estado a considerar).

Contudo, o Hinweisen (a Verweisung) auf die brachliegenden Möglichkeiten não implica que o "empreendimento de si" — em que o si sempre já se acha constituído - desapareça: dê lugar a outra coisa diferente dele.

O que acontece é, antes, que o "empreendimento de si" fica - como já referimos atrás — "em suspenso": vê ser posta "em suspenso" ("entre parênteses") a evidência em que sempre já "labora"; de tal sorte que o "empreendimento de si" como que "sai do anonimato" em que habitualmente se encontra e passa a ser "visto explicitamente".

Ora, a "suspensão" (ou "a posição entre parênteses") da execução do "empreendimento de si" - a "suspensão" (ou a "posição entre parênteses") da tensão existencial sempre já em curso para a realização plena do si mesmo - faz eo ipso "suspender" (põe eo ipso "entre parênteses") a "adesão automática" habitual às possibilidades por via das quais o "empreendimento de si" sempre já se acha em curso.

Noutros termos: no próprio momento em que o "empreendimento de si" é posto "em suspenso" ou "entre parênteses" (quer dizer: no próprio momento em que a relação do si mesmo consigo mesmo e com os restantes entes se torna gleichgültig, passa a ficar "afectada" por Gleichgültigkeit) dá-se uma remissão - um Hinweisen auf... ou uma Verweisung auf... - para algo que se nos "apresenta", se nos "indica" ou se nos "oferece a ver": o próprio "empreendimento de si" enquanto tal e as próprias possibilidades do "empreendimento de si" enquanto tais.

Como Heidegger diz:

"In solchem Ansagen der versagten Möglichkeiten liegt so etwas wie der Hinweis auf anderes, auf die Möglichkeiten als solche, auf die brachliegenden Möglichkeiten als Möglichkeiten des Daseins." 38

38 GA 29/30 214. 


\section{O empobrecimento (Verarmung) ou a nudez (Nacktheit) do si mesmo (das Selbst) e o estilhaçamento da situação (Sprengung der Situation)}

$\mathrm{Na}$ experiência do tédio profundo dá-se, portanto, uma "suspensão" da execução habitual do "empreendimento de si mesmo"; essa "suspensão" põe a descoberto o "empreendimento de si mesmo" enquanto tal e as possibilidades desse "empreendimento de si mesmo" enquanto tais.

Neste sentido, como já referimos acima, a experiência do tédio profundo "revela" a solidão ou a "saudade" em que o si mesmo — o Dasein ou o "aí de lucidez" que constitui o si mesmo — sempre já se acha: a solidão ou a "saudade" do si mesmo em relação a si mesmo, quer dizer: a solidão ou a "saudade" que consiste no facto de o si mesmo se achar sempre já "à distância" de si mesmo a haver (no facto de até a tensão existencial que "prende" sempre já o si mesmo ao "empreendimento de si" se "revelar" como totalmente indiferente).

Isso significa: na solidão (tal como está descrita em GA 29/30) fica-se "separado" não só do "outro" que se é, mas também e sobretudo da própria "tensão" para o "alcançar". Assim, aquilo que se acha "ausente" na solidão — aquilo em relação ao qual se está só ou "se sente saudade" — é si mesmo (o "outro" que é si mesmo), sim: mas enquanto se é a própria "tensão" do "empreendimento de si".

Ora, é justamente esta solidão ou "saudade" que - segundo Heidegger em GA 29/30 — está sempre já em causa na filosofia e na existência humana.

Se estamos bem lembrados, dissemos no início do presente estudo que Heidegger - em GA 29/30 - procura interpretar o tédio profundo (e a solidão ou a "saudade" que por meio desse fenómeno se "mostra" sempre já a determinar a filosofia e a existência humana) a partir da temporalidade do Dasein.

É precisamente essa questão que se trata agora de considerar.

Como encaminhamento para a consideração da questão da temporalidade do tédio profundo, vejamos um pouco mais detidamente a remissão (o Hinweisen auf... ou a Verweisung auf...) de que há pouco falámos.

A esse respeito chamámos a atenção para duas coisas:

1) para o facto de o "empreendimento de si" ficar "em suspenso" e

2) para a circunstância de essa "suspensão" produzir eo ipso uma remissão para as possibilidades do "empreendimento de si" que se "anunciam" na sua "indisponibilidade" ou irrelevância.

Se considerarmos que o si mesmo - no curso daquilo que designámos como o "empreendimento de si" — se acha sempre já na execução de possibilidades determinadas (possibilidades com que o si mesmo se "identifica" e por meio das quais procura realizar a "tensão" para a plenitude de si que 
o caracteriza), a "suspensão" do "empreendimento de si" que referimos e a simultânea "inutilização" das possibilidades por meio das quais o "empreendimento de si" se executa produzem um "esvaziamento" ou um "empobrecimento" (Verarmung) do si mesmo.

Heidegger também diz que o si mesmo fica então num "estado de nudez" (Nacktheit):

"Doch das in all dem belanglos werdende Selbst des Daseins verliert damit nicht seine Bestimmtheit, sondern umgekehrt, diese eigentümliche Verarmung, die mit diesem res ist einem langweilig` bezüglich unserer Person einsetzt, bringt das Selbst erst in aller Nacktheit zu ihm selbst als das Selbst, das da ist und sein Da-sein übernommen hat. Wozu? Es zu sein."39

Como o passo citado claramente indica, a "suspensão" do "empreendimento de si" e a "inutilização" das possibilidades por que este sempre já se executa remetem o si mesmo para si mesmo: para o próprio Dasein ou para o próprio "aí de lucidez" que constitui o si mesmo enquanto tal.

Mais do que isso, a "suspensão" e a "inutilização" referidas - e não esqueçamos que são os "efeitos" simultâneos da "ocorrência" do tédio profundo - põem o si mesmo "perante" si mesmo na facticidade que o caracteriza: na inanulabilidade da relação que tem consigo mesmo (com o "empreendimento de si" em que consiste) e com os restantes entes (com os entes "no meio" dos quais se acha numa "tensão" constitutiva para a plenitude de si).

Neste sentido, o tédio profundo põe o si mesmo "perante" o facto do "aí" da tensão existencial que de cada vez se executa - que de cada vez se acha "dirigida" à totalidade de si mesmo ainda a haver - "no meio" do todo do ente.

Heidegger também se refere a este fenómeno peculiar da "revelação" do facto do "aí" dizendo que então se dá uma Sprengung der Situation:

"Aber nicht nur alles Seiende der betreffenden Situation, in der wir zufällig sind, da, wo dieses res ist einem langweilig` aufsteigt, sondern das res ist einem langweilig/sprengt gerade die Situation und stellt uns in die volle Weite dessen, was je dem betreffenden Dasein als solchem im Ganzen offenbar ist, offenbar je gewesen ist und je sein könnte. Dieses Seiende im Ganzen versagt sich, und das wiederum nicht nur in einer bestimmten Hinsicht, mit Rücksicht auf ein Bestimmtes, in Absicht auf Bestimmtes, das wir mit dem Seienden etwa anfangen wollten, sondern dieses Seiende im Ganzen in der genannten Weite nach jeder Hinsicht und in jeder Absicht und für jede Rücksicht. Dergestalt im Ganzen wird das Seiende gleichgültig." ${ }^{40}$

39 GA 29/30 215.

40 GA 29/30 215. Cf. também GA 29/30 218: “Alles — in aller Hinsicht, Rücksicht und Absicht zumal entzieht sich das Seiende." 
Este passo dá-nos indicações decisivas sobre o significado da expressão Sprengung der Situation, bem como sobre a ligação do fenómeno que a expressão refere com a temporalidade própria do tédio profundo.

Assim, Sprengung der Situation designa uma "ruptura" do modo habitual de o si mesmo estar na situação em que de cada vez está.

De acordo com esse modo habitual de estar numa situação, o si mesmo acha-se de cada vez numa relação com algo determinado (acha-se de cada vez a realizar uma possibilidade determinada). O sentido fundamental dessa relação - o sentido cuja evidência não é posta em questão - é o de um "a caminho" da plenitude do si mesmo.

O que sucede no tédio profundo - na Sprengung der Situation que o tédio profundo "provoca" - é que se dá uma "suspensão" da evidência da situação em que então se está e eo ipso uma "suspensão da execução" (assente em tal evidência) da possibilidade aí em causa.

Noutros termos, com a "ocorrência" do tédio profundo — porque (como vimos) se dá uma "suspensão" do "empreendimento de si" e da evidência fundamental em que o "empreendimento de si" assenta — dá-se também uma "suspensão" da execução da possibilidade que de cada vez se está a realizar (isto é: da possibilidade que de cada vez se executa como "meio" ou "contributo" para a realização plena do "empreendimento de si").

O mesmo é dizer: com a "ocorrência" do tédio profundo dá-se também uma "suspensão" da situação particular em que de cada vez se está, na medida em que o sentido fundamental da situação em causa reside no próprio "empreendimento de si" (no próprio facto de a situação em causa constituir essencialmente uma mera "etapa" do "a caminho" fundamental para o "pleno de si" em que a existência humana consiste).

Com efeito, no tédio profundo a situação em que se está - enquanto "contributo" para a realização da plenitude do si mesmo - "entra em colapso". O si mesmo deixa de estar "embarcado" na situação em que se acha. Pois, na verdade, essa situação deixa de ser evidente no "contributo" que pode dar para a realização da plenitude do si mesmo. A situação em que se está torna-se aliás - como temos referido - indiferente ou irrelevante, em virtude da indiferença ou irrelevância com que o próprio "empreendimento de si" passa a "aparecer" na experiência do tédio profundo.

Dá-se portanto um "estilhaçamento" da situação particular em que se está quando o tédio profundo "ocorre": um "estilhaçamento" que se fica a dever à indiferença em que "cai" o próprio "empreendimento de si". Não, todavia, porque o "empreendimento de si" desapareça ou se encontre uma alternativa para ele; mas porque o "empreendimento de si" passa a ficar "em suspenso" e eo ipso a "manifestar-se" enquanto tal. Então, tudo — o todo do ente - passa a "aparecer" como algo sempre já "tornado possível" no seu 
“aparecer" pela condição de possibilidade do "aparecer" de tudo, ou seja: pelo próprio "empreendimento de si".

Nos termos precisos por que Heidegger se exprime, o "estilhaçamento" da situação que está em causa na experiência do tédio profundo põe-nos põe o si mesmo que é cada um de nós - em contacto com "a amplitude plena" (die volle Weite) da totalidade do que nos pode aparecer, com "a amplitude plena" (die volle Weite) do horizonte de toda a manifestação possível.

E tanto significa - segundo Heidegger - que o "estilhaçamento" da situação "operado" pelo tédio profundo nos põe (põe cada si mesmo) em ligação com a totalidade do horizonte do tempo em que cada coisa pode aparecer como o que é.

Dito de outro modo, o "estilhaçamento" da situação põe-nos (põe cada si mesmo) em ligação com a totalidade do horizonte do tempo, que torna possível

a) o próprio presente ("objecto" de uma Hinsicht),

b) o próprio passado ("objecto" de uma Rücksicht) e

c) o próprio futuro ("objecto" de uma Absicht).

Mais precisamente: no tédio profundo o que acontece é que a relação com cada coisa - com cada uma das dimensões temporais que tornam possível o "aparecer" de cada coisa no que cada coisa é - se torna gleichgültig.

De tal modo que aquilo com que a Sprengung der Situation nos põe em contacto é, em bom rigor, não cada uma das dimensões do tempo como habitualmente o compreendemos - a Gegenwart da Hinsicht, a Gewesenheit da Rücksicht ou a Zukunft da Absicht -, mas sim o próprio horizonte total e originário do tempo na sua unidade e simplicidade (o próprio horizonte total e originário do tempo que implica uno tenore a totalidade da Sicht e se articula nas diversas Sichten que referimos):

"Dieses Zumal-Ganze der Sicht, in der das Dasein sich ständig bewegt mag die eine verstellt, umnebelt, mag die andere einseitig bevorzugt sein -, das Zumal dieser drei Sichten geht und verteilt sich in die Gegenwart, Gewesenheit und Zukunft. Diese drei Sichten sind kein Nebeneinander, sondern ursprünglich einig und einfach im Horizont der Zeit als solcher. Es ist ursprünglich der eine und einheitliche All-Horizont der Zeit. Alles Seiende versagt sich in seinem Was und Wie zumal, wir sagten: im Ganzen. Das heißt jetzt: in einem ursprünglich einigenden Horizont der Zeit." ${ }^{41}$

41 GA 29/30 218. 


\section{Ser banido do horizonte do tempo (das Gebanntsein vom Zeithorizont)}

Como vimos há pouco, a experiência do tédio profundo põe o si mesmo em contacto com o próprio "aí de lucidez" (com o próprio $D a$ ) que o constitui. Esse "aí de lucidez" (esse $D a$ ) está assente - como agora observámos - no próprio horizonte total e originário do tempo na sua unidade e simplicidade.

Este dado não é de somenos importância. Pois, vendo bem, chama a nossa atenção para um aspecto bastante decisivo na compreensão do que se passa no tédio profundo e na solidão ou "saudade" que o tédio profundo "revela" como condição de facto da filosofia e da existência humana.

Esse aspecto tem que ver com a circunstância de o sentido fundamental do "aí de lucidez" (isto é: o "empreendimento de si") estar temporalmente enraizado: estar assente numa ligação constitutiva ao horizonte total e originário do tempo na sua unidade e simplicidade.

Mais precisamente, o "empreendimento de si" (o sentido fundamental do próprio $D a$ enquanto tal) está sempre já numa relação constitutiva com o horizonte da temporalidade, na medida em que a sua execução - a execução das possibilidades por meio das quais se realiza — depende da própria "fluência" habitual do tempo: depende de o tempo "integrar" o si mesmo no seu próprio curso; e, como é bem de ver, o curso do tempo equivale justamente ao curso do próprio "empreendimento de si" (ao curso do próprio "encaminhamento" para o - ou do próprio "a caminho" do — si mesmo ainda a haver).

Neste sentido, se — por um lado — é o tempo que "integra" o si mesmo no seu curso (e torna assim possível a execução habitual do "empreendimento de si"), por outro lado - segundo Heidegger — é também o tempo (o tempo na sua unidade e simplicidade) que - no momento em que o tédio profundo "ocorre" - "bane" ou "expulsa" (bannt) o si mesmo da "fluência" temporal em que o "empreendimento de si" habitualmente decorre.

Numa palavra: é o próprio tempo "aquilo que bane" ou "aquilo que expulsa" (das Bannende) o si mesmo da execução "automática" do "empreendimento de si".

Mais: é o próprio tempo "aquilo que bane" ou "aquilo que expulsa" das Bannende - o si mesmo da própria execução do "empreendimento de si" enquanto tal (ao tornar gleichgültig ou ao "afectar" de Gleichgültigkeit a própria raiz da "implantação" - uma "implantação" que é disposicional da relação com das Seiende im Ganzen):

"Es ist einem langweilig. Diese Stimmung, in der das Dasein überall ist und doch nirgends sein mag, hat das Eigentümliche des Gebanntseins. Das Bannende ist nichts anderes als der Zeithorizont. Die Zeit bannt das Dasein, aber nicht 
als die stehengebliebene im Unterschied zum Fluß, sondern die Zeit jenseits von solchem Fließen und seinem Stehen, die Zeit, die je das Dasein selbst im Ganzen ist." 42

"Das Bannende in dieser Stimmung ist nicht der bestimmte Zeitpunkt, in dem die betreffende Langeweile aufsteigt; denn dieses bestimmte Jetzt versinkt mit einem Schlage; das Zeichen dafür ist, daß wir uns um die Uhr und dergleichen überhaupt nicht kümmern. Das Bannende ist aber ebensowenig ein gedehnteres Jetzt, etwa die Zeitspanne, während der diese Langeweile anhält. Sie braucht gar keine solche, kann blitzartig wie ein Moment uns fassen, und doch, gerade in diesem Moment ist die ganze Weite der ganzen Zeit des Daseins da und gar nicht eigens gegliedert und abgegrenzt nach Vergangenheit und Zukunft. Weder nur Gegenwart, noch nur Vergangenheit, noch nur Zukunft, aber ebensowenig diese zusammengerechnet - sondern ihre ungegliederte Einheit in der Einfachheit dieser Einheit ihres Horizontes zumal." 43

\section{O agora (Jetzt) e a unidade (Einheit) do tempo (Zeit) na sua simplicidade (Einfachheit)}

Heidegger estabelece uma ligação essencial entre esta "expulsão" do si mesmo "para fora" do curso habitual do tempo do "empreendimento de si" e aquilo a que chama o Augenblick.

Segundo Heidegger, com efeito, o Augenblick é uma determinada modalidade do tempo: uma modalidade do tempo cuja peculiaridade consiste no facto de "pôr" o si mesmo num "contacto" explícito com a temporalidade enquanto tal.

No segundo dos dois passos que acabámos de citar, Heidegger chama a nossa atenção para a circunstância de o tédio profundo não provocar apenas o "contacto" explícito com o "agora" (Jetzt): com o "agora distendido" (gedehntes Jetzt) ou com a "extensão de tempo" (Zeitspanne) em que o tédio profundo "ocorre" e durante a qual se mantém.

42 GA 29/30 221.

43 GA 29/30 222. Fernando Pessoa, no Livro do desassossego, descreve com toda a propriedade este carácter súbito da "ocorrência" do tédio profundo — da solidão ou "saudade" do si mesmo em relação a si mesmo que o tédio profundo é capaz de "revelar" —: "Tudo quanto tenho feito, pensado, sido, é uma somma de subordinações, ou a um ente falso que julguei meu, por que agi d'elle para fóra, ou de um peso de circumstancias que suppuz ser o ar que respirava. Sou, neste momento de vêr, um solitario subito, que se reconhece desterrado onde se encontrou sempre cidadão. No mais intimo do que pensei não fui eu.” (F. PESSOA, Livro do desassossego, t. I, ed. Jerónimo Pizarro, Lisboa, Imprensa Nacional-Casa da Moeda, 2010, p. 224) 
No tédio profundo dá-se - segundo Heidegger - um "contacto" explícito com o tempo; mas esse tempo com que explicitamente se contacta é - em cada agora em que o tédio profundo "ocorre" - "a amplitude total" (die volle Weite) do tempo que constitui o "aí de lucidez" do si mesmo: desse tempo que — na tese de Heidegger — se caracteriza pela sua "unidade não articulada" (ungegliederte Einheit).

\section{Momento de revelação (Augenblick) e abertura do Dasein a si mesmo (das Sichentschließen des Daseins zu sich selbst)}

O Augenblick é assim uma modalidade do tempo; mas uma modalidade do tempo que se caracteriza pela sua "lucidez" em relação à própria raiz disposicional do tempo de que é uma modalidade.

Trata-se pois de uma modalidade "lúcida" do tempo: em que o próprio tempo "depõe" o si mesmo quando o tédio profundo "ocorre"44.

Ora, aquilo que o Augenblick (a "lucidez" que o caracteriza) "revela" é, mais precisamente, o tempo próprio (a temporalidade própria) do "empreendimento de si".

Nos exactos termos de que Heidegger se serve, o Augenblick - o "momento de revelação" ou o "instante de revelação" - "abre e mantém aberta" (öffnet und hält offen) "a situação do agir em toda a sua amplitude" (die volle Situation des Handelns).

$\mathrm{Ou}$ - como Heidegger também diz — aquilo que o Augenblick (o "olhar" ou a forma de "perspectiva" em que consiste) torna manifesto é o próprio $D a$ (o "empreendimento de si" que constitui o sentido fundamental do $D a$ ) enquanto "tarefa" - Aufgabe — do si mesmo:

"Dieses Sichentschließen des Daseins aber zu sich selbst, d.h. dazu, inmitten des Seienden je das Bestimmte zu sein, was zu sein ihm aufgegeben ist, dieses Sichentschließen ist der Augenblick." 45

"Der Augenblick ist nichts anderes als der Blick der Entschlossenheit, in der sich die volle Situation eines Handelns öffnet und offenhält." 46

44 Cf. GA 29/30 224: "Die Hingezwungenheit des Daseins in die Spitze des eigentlich Ermöglichenden ist das Hingezwungensein durch die bannende Zeit in sie selbst, in ihr eigentliches Wesen, d.h. an den Augenblick als die Grundmöglichkeit der eigentlichen Existenz des Daseins.

Es ist einem langweilig. Darin sagt die im Ganzen bannende Zeit sich selbst als das an, was gebrochen werden soll und einzig gebrochen werden kann im Augenblick, darin die Zeit selbst als das eigentlich das Dasein in seinem Handeln Ermöglichende am Werk ist."

45 GA 29/30 224.

46 GA 29/30 224. 
Neste sentido, como os dois passos agora citados o indicam, o Augenblick é o "momento de revelação" ou o "instante de revelação" próprio da Entschlossenheit: o "momento de revelação" ou o "instante de revelação" que produz aquilo a que Heidegger chama o Sichentschließen des Daseins zu sich selbst.

Isto significa - mais exactamente - que no tédio profundo o si mesmo "vê" como que "desfeito" o seu aparente "fechamento" na situação particular em que o "empreendimento de si" de cada vez se executa; o si mesmo ganha - eo ipso - "perspectiva" para a totalidade do "empreendimento de si": para a totalidade do $D a$ enquanto totalidade relativa a uma tarefa (a tarefa da realização plena da existência própria).

Aqui importa referir um aspecto decisivo.

Esse aspecto diz respeito ao facto de o Augenblick - enquanto é provocado pela experiência do tédio profundo - corresponder a uma peculiar forma de abertura à tarefa fundamental do si mesmo.

Pois, vendo bem, o Augenblick do tédio profundo produz aquilo a que Heidegger chama Verschwinden der Kürze der Weile ou Entschwinden der Schärfe und Spitze eines je bestimmten Augenblickes der Handlung und des Existierens:

"Das Langwerden ist ein Verschwinden der Kürze der Weile. Aber die Kürze ist entsprechend wie die Länge nicht als quantitativ kleine Dauer gedacht, sondern das Entschwinden der Kürze ist das Entschwinden der Schärfe und Spitze eines je bestimmten Augenblickes der Handlung und des Existierens." ${ }^{47}$

O sentido daquilo que acabamos de referir só pode ser percebido se o contrastarmos com um outro modo de conceber o Augenblick, designadamente: aquele nos termos do qual o Augenblick consiste na "perspectiva" própria de uma determinada acção que é realizada em expressa "sintonização" pela tarefa fundamental do "empreendimento de si".

Ora, no Augenblick do tédio profundo passa-se algo diferente.

No Augenblick do tédio profundo, há também uma relação expressa com a tarefa fundamental do "empreendimento de si" (com a tarefa fundamental de se ter de ser o próprio $D a$ enquanto totalidade do "empreendimento de si"); mas de tal sorte que o si mesmo não está "empenhado" nisso: não está "dirigido" a isso com a intensidade que caracteriza o "envolvimento" numa tarefa.

É de certa maneira o que Heidegger procura exprimir quando fala de um Entschwinden der Schärfe und Spitze eines je bestimmten Augenblickes der Handlung und des Existierens.

47 GA 29/30 229. 
Este "desaparecimento" (ou "enfraquecimento") da intensidade do "envolvimento" no "empreendimento de si" — da intensidade que torna relevante e "pressionante" uma situação particular relativa ao "empreendimento de si" - faz que o momento temporal determinado em que de cada vez se existe perca a "circunscrição" que habitualmente o define enquanto momento específico que nos diz respeito e "interpela".

Numa palavra, é esse "desaparecimento" (ou "enfraquecimento") que faz que a Weile em que de cada vez se existe deixe de ser kurz e se torne lang: se torne numa Lange-weile.

\section{Momento de revelação e isolamento (Vereinzelung)}

Aqui voltamos a tocar um ponto fundamental: o Augenblick do tédio profundo - ao exprimir a perda de "envolvimento" do si mesmo no "empreendimento de si mesmo" - exprime também a solidão (ou o isolamento) peculiar que se "revela" ao si mesmo na experiência do tédio profundo; trata-se pois da solidão - ou do isolamento - equivalente ao facto de o si mesmo ainda a haver, além de "distante", se mostrar enquanto tal também como totalmente irrelevante (como algo cuja plena "obtenção" ou realização é totalmente indiferente para o si mesmo que já se é).

Por outras palavras: o Augenblick revela ao si mesmo a solidão (ou o isolamento) que - segundo Heidegger - caracteriza de raiz o acontecimento da filosofia e o acontecimento da existência humana enquanto tal.

Com efeito, aquilo com que o Augenblick "põe" o si mesmo em "contacto" é - como observámos - o facto de o si mesmo (o $D a$ ou o "aí de lucidez" que lhe é próprio) estar intrinsecamente constituído como "empreendimento de si", quer dizer: por meio de uma "projecção" (Entwurf) das possibilidades cuja execução realiza plenamente o si mesmo ainda a haver.

Neste sentido, podemos dizer que o Augenblick mostra ao si mesmo que, apesar da sua necessária ligação à situação fáctica em que de cada vez se encontra, o si mesmo se acha fundamentalmente constituído como "trânsito", "travessia" ou "a caminho" (Übergang) para a realização plena de si mesmo ainda a haver.

Ora, estar essencialmente constituído como Übergang é, vendo bem, estar essencialmente "deslocado" "para lá" da situação fáctica em que de cada vez se existe; é, como Heidegger diz, estar essencialmente constituído como Entrückung.

Heidegger também exprime esta "deslocação fundamental" do si mesmo "para lá" da situação fáctica - e "em direcção" à totalidade de si mesmo a haver - por meio do termo Abwesenheit. 


\section{Ausência (Abwesenheit) e espanto (Entsetzen, Staunen)}

Por meio do termo Abwesenheit Heidegger procura referir a constituição fundamental do si mesmo como "ausência": como algo que se acha "ausente" da situação fáctica em que de cada vez se encontra (no sentido em que aquilo em que fundamentalmente está "posto" é a totalidade de si mesmo ainda a haver).

Mas Abwesenheit - no presente contexto - não refere apenas isso.

Vendo bem, Abwesenheit procura referir também a circunstância de aquilo em que o si mesmo fáctico fundamentalmente se acha "posto" ser algo "ausente": algo que o si mesmo fáctico ainda não "possui" ou ainda não "alcançou".

De tal sorte que a Abwesenheit - a peculiar modalidade de "ausência" nela em questão - designa o modo de ser do si mesmo - do si mesmo que cada um de nós é - como um modo de ser segundo o qual o si mesmo existe de cada vez na particular condição de alguém que se acha "nenhures": numa "terra de ninguém" (uma vez que se encontra fundamentalmente "deslocado" "para lá" do que facticamente é: "em direcção" à totalidade de si mesmo a haver que ainda não "possui" ou ainda não "alcançou"; a sua condição de facto é a deste "a caminho": a deste "a meio caminho" da realização plena de si mesmo).

Ora, a Abwesenheit — tal como acabamos de a descrever - é aquilo que o Augenblick do tédio profundo (enquanto está na base do acontecimento da filosofia) propriamente "revela" ao si mesmo a respeito da sua "condição".

Não esqueçamos, porém, que o Augenblick do tédio profundo não "revela" ao si mesmo - como já vimos - o facto inanulável do "empreendimento de si" enquanto algo em que o si mesmo está "empenhado" ou "envolvido".

Vimos aqui - pelo contrário - que o Augenblick do tédio profundo "revela" ao si mesmo o "empreendimento de si" (o estar sempre já "saído" "para lá" da situação fáctica "em direcção" à totalidade de si ainda a realizar) como algo em que o si mesmo não está "empenhado": algo que não é de todo evidente na "validade" que tem: algo que é eminentemente problemático ou "enigmático" quanto ao seu significado e "valor".

E, com efeito, esta problematicidade (este carácter "enigmático") do próprio "empreendimento de si" (da própria tensão existencial para a realização plena da totalidade de si a haver) - enquanto é "revelada" pelo Augenblick do tédio profundo - que, segundo Heidegger em GA 29/30, produz o acontecimento da filosofia: da relação "transparente" da existência com aquilo em que propriamente consiste.

Dito de outro modo, a filosofia (a manifestação à própria existência da "ausência" fundamental que a constitui) - enquanto é provocada pelo $A u$ - 
genblick do tédio profundo - equivale, para Heidegger em GA 29/30, ao acontecimento do "espanto" (do Entsetzen ou do Staunen).

Em suma: equivale ao acontecimento de "êxtase" (Hingerissenheit) que constitui "o alento de todo o filosofar" (der Odem alles Philosophierens); ao acontecimento no qual o "empreendimento de si" e tudo quanto tem o seu sentido fundamental assente no "empreendimento de si" — isto é: o todo do ente (das Seiende im Ganzen) — são "encarados" ou "enfrentados" na problematicidade e na falta de evidência que os caracteriza (enquanto algo cujo sentido se acha ainda inteiramente por apurar):

"Entwerfend wirft das Da-sein in ihm [d.h. im Menschen] ihn ständig in die Möglichkeiten und hält ihn so dem Wirklichen unterworfen. So geworfen im Wurf ist der Mensch ein Übergang, Übergang als Grundwesen des Geschehens. Der Mensch ist Geschichte, oder besser, die Geschichte ist der Mensch. Der Mensch ist im Übergang entrückt und daher wesenhaft rabwesend . Abwesend im grundsätzlichen Sinne - nicht und nie vorhanden, sondern abwesend, indem er wegwest in die Gewesenheit und in die Zukunft, ab-wesend und nie vorhanden, aber in der Ab-wesenheit existent. Versetzt ins Mögliche, muß er ständig versehensein des Wirklichen. Und nur weil so versehen und versetzt, kann er sich entsetzen. Und nur, wo die Gefährlichkeit des Entsetzens, da die Seligkeit des Staunens - jene wache Hingerissenheit, die der Odem alles Philosophierens ist (...)." ${ }^{p 8}$

\section{Filosofia, existência e o problema da solidão}

Chegamos assim ao fim do percurso fundamental deste estudo.

Há, no entanto, algumas "pontas soltas" que convém ligar para que se torne claro o que se procurou fazer nele.

Ora, o nosso propósito foi sobretudo o de demonstrar tão claramente quanto possível que - para Heidegger (pelo menos em GA 29/30) - a solidão ou a "saudade" do si mesmo em relação a si mesmo constitui a

48 GA 29/30 531. Na medida em que o Augenblick do tédio profundo representa uma modalidade do tempo, o acontecimento da filosofia (enquanto é provocado por tal Augenblick) pode ser caracterizado - para usar de uma expressão de Heidegger em $G A$ 61 - como uma Zeitigung der Fraglichkeit: "Das eigentliche Fundament der Philosophie ist das radikale existenzielle Ergreifen und die Zeitigung der Fraglichkeit; sich und das Leben und die entscheidenden Vollzüge in die Fraglichkeit zu stellen ist der Grundergriff aller und der radikalsten Erhellung. Der so verstandene Skeptizismus ist Anfang, und er ist als echter Anfang auch das Ende der Philosophie." (M. HEIDEGGER, Gesamtausgabe. II. Abteilung: Vorlesungen. Band 61: Phänomenologische Interpretationen zu Aristoteles. Einführung in die phänomenologische Forschung. Frühe Freiburger Vorlesung Wintersemester 1921/22. Herausgegeben von Walter Bröcker und Käte Bröcker-Oltmanns. Frankfurt am Main, Vittorio Klostermann, 1985, 2. durchgesehene Auflage 1994 [=GA 61], p. 35) 
própria "forma" do acontecimento da filosofia e da existência humana enquanto tal.

Como vimos, a tese de Heidegger sobre a filosofia e a existência humana enquanto solidão ou "saudade" do si mesmo em relação a si mesmo é uma tese "adoptada" do fragmento de Novalis que diz:

"Die Philosophie ist eigentlich Heimweh, ein Trieb überall zu Hause zu sein". 49

Isso significa - como também vimos - que a tese de Heidegger em questão é, em última análise, uma tese com que Heidegger se "vê" confrontado ao ter contacto com a tradição: uma tese que Heidegger - em grande parte de GA 29/30 - procura "pôr à prova" (examinar na capacidade que tem para esclarecer que acontecimento é o da filosofia, que acontecimento é o da existência humana).

Segundo a interpretação que Heidegger faz do fragmento de Novalis, a disposição da "saudade" (Heimweh) corresponde à disposição do "tédio profundo" (tiefe Langeweile); e, por seu turno, o "em toda a parte" (überall) é - para Heidegger - nada menos do que o "mundo" (Welt).

E, com efeito, o mundo que - no acontecimento de "saudade" que é a filosofia - se trata de constituir como "casa" ou "domicílio" (Zuhause).

Disto se depreende, evidentemente, que a filosofia - enquanto acontecimento de "saudade" - não tem o mundo constituído como "casa" ou "domicílio".

Ora, o que nós procurámos mostrar foi, entre outras coisas, que - segundo Heidegger - a filosofia e a existência humana estão de raiz "afectadas" por aquilo a que chama tédio profundo, quer dizer: por terem a "condição" da "saudade" do si mesmo em relação à realização plena da totalidade de si mesmo (isto é: em relação à constituição do mundo como "casa" ou "domicílio").

Indicámos - ao longo de todo este estudo (mas sobretudo a partir da análise do Augenblick do tédio profundo) - que a solidão ou a "saudade" do si mesmo em relação a si mesmo (a solidão ou a "saudade" que caracteriza a filosofia e a existência humana enquanto tal) consiste na "indiferença" — na "problematicidade" - com que o próprio "empreendimento de si" se apresenta ao si mesmo: ao próprio si mesmo que se encontra indespedivelmente nessa tensão existencial para a realização plena da totalidade de si (isto é: para a constituição do mundo como "casa").

Segundo o que indicámos, com efeito, é a própria "tensão" ou "pulsão" (Trieb) para a constituição do mundo como "casa" - é o próprio "empreendimento" de si (de realização plena da existência) — que, no Augenblick do tédio profundo (enquanto aquilo que provoca o acontecimento da filosofia),

49 Cf. GA 29/30 7. 
se "manifesta" como "indiferente" ou "irrelevante": "espantoso" ou "problemático", "misterioso" ou "enigmático".

A filosofia é portanto essa relação de "espanto" do si mesmo com a totalidade de si mesmo ainda a haver: com a totalidade do mundo enquanto totalidade do "empreendimento de si".

Trata-se pois de uma solidão ou de uma "saudade" que caracteriza de raiz a filosofia e a existência humana, mas que habitualmente se acha "oculta" ("escondida", "não revelada" ao si mesmo). E além disso trata-se de uma solidão ou de uma "saudade" que — quer se ache "detectada" pelo si mesmo quer se mantenha "oculta" para ele - está sempre já "em funcionamento" em todas as modalidades da existência humana (inclusivamente na filosofia) e em todas as modalidades da existência humana (inclusivamente na filosofia) está sempre já constituída como "tensão" para a sua própria "supressão".

A este respeito tem de ser suscitada a seguinte questão: trata-se aqui de uma solidão ou de uma "saudade" de facto (de uma solidão ou de uma "saudade" que caracteriza de facto a situação da filosofia e da existência humana)? Ou trata-se - pelo contrário — de uma solidão ou de uma "saudade" inanulável, inultrapassável (a despeito de toda a "tensão" que possa haver para a "supressão" da situação a que corresponde)?

Há na verdade alguns passos da obra do "primeiro Heidegger" que parecem sustentar a tese de que a filosofia - e nesse sentido a solidão ou a "saudade" em que a filosofia consiste - não é "suprimível", de sorte que constitui como que uma condição necessária (permanente ou - se assim se pode dizer - "transcendental") da existência humana. ${ }^{50}$

Outros passos há, no entanto, em que Heidegger afirma que a filosofia a solidão ou a "saudade" em que a filosofia consiste — é uma modalidade da existência humana que corresponde a um Vorletztes: a algo de provisório que deve ser "ultrapassado" (überwunden) ${ }^{51}$.

Esta é - parece-nos - a alternativa mais plausível: aquela que mais se acha de acordo com a nossa real situação de acesso ao que pode vir a ser o destino da filosofia (da solidão ou "saudade" que nos caracteriza). Pois vendo bem - se, por um lado, nos é possível verificar que a filosofia (enquanto solidão ou "saudade") nos constitui na nossa situação de facto, por

50 Veja-se por exemplo o trecho de $G A 61$ que citámos na nota 48.

51 Cf. GA 29/30 232: "Wer die innere Freiheit dazu nicht aufbringt, als Philosoph ein solcher Mensch zu sein, zu dessen Wesen es gehört, besser verstanden werden zu müssen als er sich selbst versteht, an dem ist die Philosophie trotz aller philosophischen Gelehrsamkeit vorbeigegangen. Philosophie ist nur da, um überwunden zu werden. Aber das kann sie nur, wenn sie erst steht, und kann es um so wesentlicher, je tiefer der Widerstand ist, den sie durch ihr Dasein aufbringt." 
outro lado, não nos é possível antecipar se vai ser assim "para todo o sempre" e apesar de todos os esforços em contrário.

Mas, de todo o modo, é essa a situação de facto em que se está; trata-se de uma situação de facto que - no próprio esforço para se "suprimir" — não pode deixar de pôr em evidência a solidão ou "saudade" em que consiste, quer dizer: não pode deixar de pôr em evidência a circunstância de — apesar de toda a consciência que já pode haver de que a "condição" própria é a dessa solidão ou "saudade" (e apesar de todo o esclarecimento que isso já possa produzir sobre a situação em que se está) - se ter de determinar ainda e sempre: que solidão ou "saudade" é essa?, faz-se "sentir" em relação a quê?, como deve ser "suprimida" ou "ultrapassada"?, etc., etc.

Entretanto - enquanto a situação de solidão ou "saudade" não for "ultrapassada" (e a sua "ultrapassagem" implica não só a determinação de tudo o que agora se indicou, mas também o ser e o agir em conformidade com tudo isso ${ }^{52}$ - - a "condição" da filosofia e da existência humana é a do "a caminho" ou a do "a meio caminho" em que até agora sempre se esteve.

52 É também porque fica aquém do agir que — segundo Heidegger — a filosofia é algo Vorletztes: "Wenn es hoch kommt, wird sie [d.h. die Not des heutigen Daseins] nur verschärft, verschärft in dem einzig möglichen Sinne, daß uns dieses Fragen an den Rand der Möglichkeit bringe, der Möglichkeit, dem Dasein wieder Wirklichkeit, d.h. seine Existenz zu geben. Aber zwischen diesem äußersten Rande der Möglichkeit und der Wirklichkeit des Daseins ist freilich eine dünne Linie, jene Linie, über die man nie hinweggleiten kann, aber jene Linie, die der Mensch nur überspringt, wenn er seinem Dasein einen Ruck gibt. Von diesem Rand des Möglichen in den Ruck zur Wirklichkeit führt nur das einzelne Handeln selbst - der Augenblick. Das Philosophieren dagegen kann nur bis an den Rand führen; es bleibt immer im Vor-letzten." (GA 29/30 257) Mas, apesar de ficar aquém do agir, a filosofia desempenha - para Heidegger — um papel decisivo no esclarecimento e na "condução" da existência: "Aber selbst da kann es [d.h. das Philosophieren] nur hinführen, wenn es wirklich vorläuft in dieses Vor-letzte und so seine ganze Vorläufigkeit und Endlichkeit begreift, d.h. begreift, daß es nicht leer und bieder in mehrerlei, vielleicht richtigen Untersuchungen sich ergehen darf, um das Übrige dem lieben Gott und dem Zufall zu überlassen, das Übrige, nämlich das Wesentliche: wirklich bis an den Rand der Möglichkeiten zu führen und zuvor die Möglichkeit und den jeweiligen Weg einer solchen Führung zu bereiten." (GA 29/30 257)

Segundo Heidegger, a filosofia é algo Vorletztes em relação ao "agir" (Handeln) em dois sentidos: 1) a filosofia não produziu ainda o esclarecimento integral da situação de facto em que se acha; 2) a filosofia - enquanto investigação de carácter "ontológico" (ontologisch) - fica aquém do "agir" (Handeln) por não se "inscrever" automaticamente na existência concreta (ontisch) de cada si mesmo. Não desenvolveremos aqui a questão como na verdade mereceria ser desenvolvida; sobretudo porque não nos parece constituir um aspecto central do principal tema das nossas averiguações no presente estudo. Contudo, não quisemos deixar de indicar a articulação fundamental do problema em vista de uma possível averiguação futura a seu respeito. 
É essa condição fáctica de "a caminho" ou de "a meio caminho" que segundo Heidegger - caracteriza a própria perspectiva filosófica (a própria perspectiva da analítica existencial).

Trata-se da perspectiva a partir da qual - em todo o nosso estudo procurámos considerar a solidão; e trata-se também da perspectiva que (no esclarecimento da Einsamkeit: da "saudade" do si mesmo em relação a si mesmo) se "descobre" num "processo de auto-esclarecimento": num "processo de auto-esclarecimento" que - mesmo depois de a perspectiva filosófica se "descobrir" como solidão ou "saudade" — ainda se mantém e tem de manter porque a "opacidade" só assim não se "dissipa".

Nesse sentido, a "descoberta" da filosofia e da existência humana como solidão (ou "saudade" do si mesmo em relação a si mesmo) não equivale senão à "redescoberta" de um problema, a saber: à "redescoberta" do problema da filosofia e da existência como o problema da solidão humana (quer dizer: como o problema da "saudade" do si mesmo de cada ser humano em relação a si mesmo). 